\title{
Tigranokerta Savaşı (MÖ 69): Yeni Bir Gözden Geçirme*
}

\section{The Battle of Tigranocerta (69 BC): A Reconsideration}

\author{
Muzaffer Demir ${ }^{1}$ (1)
}

*Bu çalıșmanın özeti 27-29 Nisan 2008 tarihleri arasında Silvan'da düzenlenen Uluslararası Silvan Tarihi Sempozyumu'unda sunulmuş, basılmamıştır.

1Muğla Sıtkı Koçman Üniversitesi, Edebiyat Fakültesi, Tarih Bölümü, Muğla, Türkiye

\section{ORCID ID: M.D. 0000-0002-5661-1607}

Sorumlu yazar/Corresponding author: Muzaffer Demir (Prof. Dr.),

Muğla Sıtkı Koçman Üniversitesi, Edebiyat

Fakültesi, Tarih Bölümü, Muğla, Türkiye

E-posta:dmuzaffer68@gmail.com

Başvuru/Submitted: 16.03.2021

Kabul/Accepted: 30.04 .2021

Atıf/Citation: Demir, M. (2021). Tigranokerta savaşı (Mö 69): Yeni bir gözden geçirme. Anadolu Araştırmaları-Anatolian Research, 24, 145-176. https://doi.org/10.26650/anar.2021.24.898025

\section{öz}

Tigranokerta (Tigranakert) kentinin Siirt illi Kurtalan İlçesi Bozhöyük köyü yakınlarındaki bugünkü Antik A/Erzen yerleşimi olduğu düşünülmektedir. Armenia kralı II. Tigranes, MÖ 76 yılından itibaren Kappadokia, Kilikia, Suriye ve Parthia içlerine kadar yayılmış olan imparatorluğunun sınırlarının daha merkezinde olduğundan dolayı bu kenti kurmuştur. Zengin ve görkemli olduğu söylenen kent, imparatorluğun yeni başkenti olmuş ve başta Kappadokialılar olmak üzere pek çok halk burada iskâna zorlanmıştır. Kent aynı zamanda MÖ 69 yılında II. Tigranes ve Roma generali Lucullus arasında tarihin önemli savaşlarından birisine sahne olmuştur. Roma proconsulu Lucullus'un legatuslarından Sextilius ve Murena, kent yakınlarında meydan savaşı başlamadan önce düşman destek birliklerinin önünü keserek zafer elde etmişlerdir. Sonrasında Sextilius, Mankaios'un garnizon komutanlığını yaptığı kenti kuşatmaya başlamıştır. II. Tigranes'in Lucullus'un ordusunu sayıca küçük gördüğünden müttefiki Pontos (Karadeniz) kralı Vl. Mithradates'in meydan savaşından kaçınması gerektiği yönündeki tavsiyesini dinlemediği iddia edilmektedir. Ancak Lucullus II. Tigranes'i ağır bir yenilgiye uğratarak kenti ele geçirmiş, yağmalamış ve hatta zorla iskân ettirilen yabancı nüfusunun evlerine geri dönmesini sağlamıştır. Biz bu çalışmamızda, ilk önce savaş öncesi durumu, sonrasında da halen tartışma konusu olan her iki tarafın asker sayısını açıklamaya çalışacağız. Sonuçta, özellikle her iki tarafın asker sayısı hakkında bazı antik yazarların verdiği abartılı rakamların tekrar gözden geçirilmesi ve bu bağlamda savaş stratejilerinde göz ardı edilen bazı noktalar üzerinde de yeni değerlendirmeler yapılması gerekmektedir.

Anahtar Kelimeler: Armenia, II. Tigranes, Lucullus, Tigranokerta, A/Erzen

\section{ABSTRACT}

The ancient city of Tigranocerta (Tigranakert) is thought to be localized to the site of Ancient A/Erzen near Bozhöyük, which is in the district of Siirt Province. The Armenian king, Tigranes II, established this city in $76 \mathrm{BC}$, as it would be more at the center of the borders of his empire, which had spread over Cappadocia, Cilicia, Syria, Palestine, and as far as Parthia. This city, described in ancient sources as rich and magnificent, became the empire's new capital, where many people from various areas, especially Cappadocia, were forced to immigrate and settle. In 69 BC, it witnessed one of history's most significant battles between the Roman proconsul Lucullus and Tigranes II. Before the pitched battle near the city, it appears that the legates of Lucullus, Sextilius, and Murena had been sent out to harass and cut off those who marched to the support of Tigranes II. They seem to have defeated the 
enemy in all these engagements. Eventually, Sextilius started to besiege Tigranocerta, where Mankaios was in command. As the size of the Roman army appeared inconsiderable to Tigranes II and his allies, even jeering at it, they did not listen to the advice of their ally, Mithradates VI, the king of Pontus (Black Sea), to try and cut off the supplies of the Roman army. They instead preferred to engage in a pitched battle, where they were heavily defeated by Lucullus. Thus, Tigranocerta fell and was sacked, and the city's immigrant population was sent back to their homes. In this article, we first explain the circumstances before the battle and then concentrate on the question of army size on both sides, which appears to have been exaggerated by some ancient writers, and finally reevaluate their battle strategies within this conjecture.

Keywords: Armenia, Tigranes II, Lucullus, Tigranocerta, A/Erzen

\section{EXTENDED ABSTRACT}

The city of Tigranocerta (Tigranakert) is localized as today's Ancient A/Erzen near the village of Bozhöyük in the Kurtalan District of Siirt Province. In 69 BC, it was the scene of one of the most important battles in history between the Armenian king Tigranes II and the Roman general Lucullus. Significant conflicts took place before the field battle started. At the first stage, while Lucullus advanced to Tigranocerta, he attacked some Armenian cities in the region and defeated Mithrobarzanes, whom Tigranes II sent against him. At the second stage, the vanguard troops under the command of Sextilius both besieged Tigranokerta and successfully blocked and destroyed the Arab support forces from the South. Next, Murena struck the army of Tigranes II, who was going to collect his army from the north of the Taurus mountains, but the king managed to flee to the North. Meanwhile, Lucullus with his remaining army marched on Tigranocerta to support the siege. The success of the Roman army at the beginning of the war by blocking the Armenian support forces and preventing them from gathering reinforcements from the strategic areas in the North and the South contradicts the claim that Tigranes II returned and fought the Romans with an extremely superior number of soldiers.

Plutarch built his war scenario on the humiliation of the barbarians, suffering defeat despite their great numerical superiority and entertaining the Roman audience. One must approach with caution the words of Tigranes II as mentioned by Plutarch, who allegedly mocked the number of Roman soldiers. Plutarch seems to have succeeded in his scenario because the same words were repeated by Appian and Memnon, who wrote after him. Meanwhile, Plutarch glorified Lucullus by emphasizing the arrogance of Tigranes II.

The numbers reported by Plutarch and his successor Appian regarding the size of Armenia's army seem exaggerated. Plutarch preferred to use Lucullus's own propaganda letters to the senate as well as the source of Lucullus's close friend Archias. Eutropius stated that the Armenian soldiers totaled 700.000, most likely either a copying error or propaganda. As reported by Festus, this number should be 70.000. Both Memnon and Phlegon preferred to present an approximately similar number. Meanwhile, Plutarch and Appian were inclined 
to report that the size of the Roman military forces was quite small. Frontinus reported the number to be around 15.000 and Eutropius 18.000, but these numbers also seem less. As Plutarch partially and indirectly confirmed, Lucullus's army is actually around 30.000, almost half of Tigranes II's.

Instead of long-term and tedious attrition operations, Lucullus quickly took action against Tigranes II by changing tactics. Mithradates VI was delayed in joining the army of Tigranes II in battle. As a result of all these maneuvers by Lucullus, Tigranes II was forced to retreat. He entered the field battle by gathering more inexperienced troops composed of foreign allies. While the size of these military associations seems relatively large, they acted cumbersome and sluggish because of the lack of solidarity and organization among themselves. Lucullus, on the other hand, led experienced and coordinated troops. By using a clever tactic, he pretended to retreat, which would lead the enemy to think that they became victorious, thus breaking their ranks forward on the retreating Roman army and dispersing. Lucullus then swiftly moved and attempted to surround the enemy from behind with his legions, attacking their armored cavalry and carriages, causing panic and chaos among the enemy forces. The enemy troops were defeated as they lost coordination. Tigranes II had to leave the battlefield and flee.

Although Lucullus reached one of the highlights of his career with his victory at Tigranocerta, his luck began to turn because of his ambition. The Roman soldiers, who had served under him for six years, had accumulated a significant amount of money and property from the looting and therefore wanted to return to their homes as soon as possible. However, Lucullus aspired to strengthen his reputation in Rome by winning a victory against the Parthians as well. When Lucullus received the news that after taking command from Tigranes II Mithradates VI had made a secret agreement with the Parthians, and considering the unwillingness of his soldiers, he gave up on his expedition against the Parthians. Meanwhile, he decided to march up to Artaxata, where Tigranes II had withdrawn his forces. Yet a general uprising started in the army as a result of the heavy winter conditions and the lack of supplies; hence, the Armenian campaign was unsuccessful. A short while later, the senate dismissed Lucullus. 


\section{Giriş}

Eskiçağ Tarihi araştırmacılarının genelde Tigranokerta kentinin lokalizasyonu üzerine çalışmalar yaptığı görülmektedir. En son yapılan çalışmalar sonucunda kentin A/Erzen olarak lokalizasyonu genel kabul görmektedir. ${ }^{1}$ Diğer taraftan Roma proconsulu Lucullus'un II. Tigranes'in Tigranokerta kentini kurmaya devam ettiği tarihlerde kent yakınlarında gerçekleşen ve II. Tigranes ve ordusunun yenilgisi ile sonuçlanan savaşla ilgili olarak kapsamlı bir çalışmanın yapılmadığı, başka konularla bağlantılı olarak kısa değerlendirmeler yapıldığ1 görülmektedir (Özellikle bkz. Schlude, 2009, 20-25; Cameron, 2014, 419-426; Mayor, 2014, 111-115; Wilcox, 1986, 42-44).

Plutarkhos, savaştan yaklaşık yüz elli yıl sonra Tigranokerta savaşı hakkında en kapsamlı bilgilere yer veren Lucullus biyografisini yazmıştır (Plut. Luc. XVI.3-XXVII.4). Daha sonra Appianus Mithridateios (Mithradates Savaşları) ve Cassius Dio Rhomaika (Roma Tarihi) başlıklı eserlerinde, Plutarkhos'unki ile benzer kaynakları kullanarak savaşla ilgili daha kısa bilgiler sunmuşlardır. ${ }^{2}$ Plutarkhos'un savaşı anlattığı destansı kısımları Lucullus'un yakın dostu şair Arkhias’tan alarak kullanma ihtimali oldukça yüksektir. Arkhias (MÖ ca.120-61), Syria (Suriye)'da Antiokheia kentinde doğmuştur ve Hellen kökenlidir. MÖ 102 yılında ün ve şöhrete kavuştuktan sonra Roma'ya gitmiş ve burada nüfuzlu aileler arasında yer edinmeyi başarmıştır. Zamanla Lucullus'un da yakın dostu olmuş ve onun geçmişteki zaferlerini kutsayan şiirler yazmıştır. ${ }^{3}$ Plutarkhos'un Lucullus biyografisinde savaşla ilgili kısaca atıfta bulunmayı tercih ettiği Amaseialı (Amasyalı) Strabon'un “Tarihi Yorumlar” başlıklı eseri ise günümüze kadar ulaşamamıştır. ${ }^{4}$ Strabon, günümüze kadar ulaşan Geographika adlı eserinde II. Tigranes'in topraklarının nihai olarak genişlediği sınırlara ve yeni kurduğu Tigranokerta kentine Kappadokia halkının zorla göç ettirilmesine, Lucullus'un kenti ele geçirdikten sonra bu halkın evlerine geri gönderilmesine ve II. Tigranes'in özellikle Syria ve Phoenikia (Fenike) topraklarındaki hakimiyetinin son verilmesine yorum yapmadan kısa metinlerle değinmektedir (Strab. XI.14.15; XII.2.9). Strabon'un yanında Herakleialı (K. Ereğlisi) Memnon, Romalılar tarafindan MÖ 70 yılında ele geçirilinceye kadar doğduğu kentin

1 Sinclair, 1995 ve 1996-1997; Demir, 2008, 176-181; Cameron, 2014, 410-430; Marciak, 2016, 293-314; Comfort, 2017, 182. Geniş bir alana yayıldığı görülen Ortaçağ A/Erzen kentinin lokalizasyonu için bkz. Sunkar et al., 2015, 705-706.

2 App. Mith. XII.84-86; Dio Cass. XXXVI.1-8. Appianus’un Armenia kaynağı kullanmadığı düşünülmektedir (Sullivan 1971, 57 dipnot 1).

3 Taylor, 1952, 62-70.

4 Plut. Luc. XXVIII.7. Ayrıca Plutarkhos buradaki metninde filozof Antiokhos ve Livius'a da atıfta bulunmaktadır; Antiokhos, Tanrılar Hakkında başlıklı eserinde savaşın dehşetine değinirken, Livius Roma ordusunun kendisinden kat kat üstün bir düşmanı yenilgiye uğrattığına vurgu yapmıştır. Plutarkhos Lucullus biyografisinde, Sallustius'un yazdığı tarih eserinden ve ayrıca Lucullus'un Roma senatosuna bir kaç kez gönderdiği mektuplardan da faydalanmıştır (Plut. Luc. XI.4; XIII.4; XXI.7; XXVI.6; XXXIII.3; XXXV.5; Gerrish, 2012, 210). Bu mektuplara bizzat kendisinin ulaşıp ulaşamadığ tam olarak bilinmemektedir. Göründüğü kadarıyla mektupların Livius veya Sallustius’taki referanslarından alıntı yapmıştır. 
tarihini yazdığı eserinde ve Tralleisli (Aydın) Phlegon (MS II. yy.), Olimpiyat Galiplerinin Listesi ve Kronikleri başlıklı çalışmasında savaşı kısaca özetlemektedirler. Anadolu'daki gelişmeleri daha yakından takip etme firsatı bulan bu her iki Hellen yazarının eserlerinin bazı kısımları Constantinopolisli patriarkhes Photius'un (MS ca.810/820-893) Bibliotheca adlı eserinde aktardığı fragmanlar sayesinde günümüze kadar ulaşmıştır ve Tigranokerta savaşının gerçekleri ve savaşa katılan asker sayısı rakamlarıyla ilgili daha tarafsız rakamlar verdikleri görülmektedir. ${ }^{5}$

MS IV. yy.'ın ikinci yarısında İmparator Valens'in sekreterliğini (magister memoriae) yapan Eutropius'un Breviarium Historiae Romanae (Roma Tarihinin Özeti) başlıklı 77 sayfalık kısa bölümlerden oluşan eserinde savaştan makasla kesilmiş gibi kısaca bahsedilmektedir. Bu konuda bilgi veren diğer yazar Rufus Festus, Eutropius ile aynı dönemde yaşamış ve onun ardından Valens'in hem sekreterliğini yapmış hem de Asia Eyaleti proconsulu olarak görev almıştır. Bu arada Eutropius gibi imparator için Roma tarihinin özetini (epitome Breviarium rerum gestarum populi Romani/Roma Halkının İcraatlarının Özeti) yazmıştır. İki eser arasındaki ilişki tam olarak anlaşılamasa da, sadece 20 sayfadan oluşan eserini kendisinin de katılacağı Perslere karşı yürütülecek savaş öncesinde doğu eyaletlerinin tarihini görev yapan memurlara öğretmek amacıyla yazdığı düşünülmektedir (Cameron, 1969, 306). Aşağıda da açıklayacağımız üzere her iki yazar da savaşla ilgili çok kısa ve birbirine benzer ifadeler kullanmakta ve Armenia ordusundaki asker sayısını propaganda amaçlı olarak abartmaktadır.

Tigranokerta savaşıyla ilgili en detaylı bilgiyi veren Plutarkhos'un diğer eserlerinin de Roma'da büyük takdir kazandığı ve onu takip eden Appianus ve Cassius Dio'nun Roma siyaseti ve bürokrasisi içinde önemli görevler üstlendikleri bilinmektedir. Bu sebeple başta Plutarkhos olmak üzere, ilgili yazarların anlatımlarında Roma yanlısı bir tavır sergileme ihtimali öne çıkmaktadır. Nitekim Plutarkhos'un Lucullus biyografisinde savaşın abartılı bir şekilde aktarıldığı kısımlar açıkça kendini göstermektedir. Bu türden anlatımlar iki önemli özelliğe sahiptir. Birincisinde yanlış yoruma veya anlaşılmaya sebep olmamak için tarihi kayıtlardaki boşluklar bilinçli bir şekilde uydurularak doldurulmaktadır; halkın görüşünden uzak sadece önemli kişilerin gerçekte ne olduğunu bildiği şekilde derlenmektedir. Yani olayın gerçekliği içindeki negatif yönlü ve açıklanması istenmeyen tutarsızlıkların önüne geçmek için devletin veya belli bir yönetici sınıfının çıkarlarına destek olabilecek türden propaganda unsuru taşıyan detaylı veriler metne yüklenmektedir. İkincisinde ise herhangi bir liderin, elit veya etnik kesimin aldatılmasından çok eğlendirilmesi gerektiği düşünüldüğünden gerçek tarihi alt yapı ile aktaranın kendi icatları arasındaki uyuşmazlık görmezden gelinmektedir (Mulroy, 1988, 155-157). Tarihçiye düşen görev ise bu türden metinlerdeki tarihi gerçeklikleri

5 Phlegon FGr Hist 257 12.10; Memnon FGr Hist 434 38.2-6. Bu yazarlara MS I. yy. ortalarında Alexandrialı Timagenes de eklenebilir. Ancak onun Caesar dönemine kadarki olayları yazdığı Evren Tarihi adlı eseri günümüze kadar ulaşmamıştır. 
uydurma olanlardan ayırt edebilmektir. Özellikle halkın kolaylıkla doğrulayabilmesinin mümkün olmadığı, eğlendirici, kulağa hoş gelen aktarımların hayal ürünü olduğunun üzerinde durulması gerekmektedir. Plutarkhos'un Lucullus biyografisinde savaşla ilgili aktarımları hem insanın duygularını kabartmakta, hem eğlendirmekte ve hatta mizaha yer vermektedir. Savaş sahnesinin anlatımı sırasında metne eklenen uydurma kısımların duygusal etkisi çok az sayıda insan üzerine odaklanmakta ve genelde açıklamalar, sanki Plutarkhos orada savaş sahnesini seyrediyormuş gibi çok canlı detaylar içermektedir. Bütün bunların yanında Plutarkhos'un biyografisinin ana teması Lucullus'u büyük bir general olarak göstermektir. Buna binaen onun aktarımlarının yarı uydurma olduğunu ve propaganda unsuru taşıdığını aşağıda analiz edeceğimiz metinlerin detaylarında vurgulamaya çalışacağız. Bu bağlamda Tigranokerta savaşı her ne kadar niteliğin niceliğe üstün geldiği savaşlara örnek olarak gösterilse de, ilgili antik kaynaklar dikkatli bir şekilde analiz edildiğinde her iki taraf arasında sayısal farklılığın normalde tahmin edilenden daha az olduğu görülecektir.

\section{Meydan Savaşı Öncesi Gelişmeler}

Armenia krallığı, Artaxiad (Artashesia) kraliyet ailesinden II. Tigranes'in iktidarında (MÖ 95-55) en geniş sınırlarına ulaşmıştır. Başlangıçta krallığının toprakları Kur vadisinden Melitene (Malatya) ve Cappadocia’ya kadar uzanmıştır. Bu sırada Pontos (Karadeniz) kralı VI. Mithradates, Roma’ya karşı yürüteceği savaşta II. Tigranes ile ittifak kurmak istemiş, kızı Kleopatra’yı Cappadocia kralı Ariobarzanes ile evlendirmiş, diğer taraftan da II. Tigranes'in Cappadocia üzerindeki baskısına göz yummuştur. Ariobarzanes, baskılar sonucu topraklarının ilhak edilmesine boyun eğmek zorunda kalmış ve yardım için Roma'ya sığınmıştır. Böylelikle Cappadocia krallığı, II. Tigranes aracılığı ile VI. Mithradates'in kontrolü altına girmiştir (Iust. XXXVIII.1-3). Ancak Lucius Cornelius Sulla, MÖ 96 yılında Roma'nın Cilicia propraetoru olarak atandıktan sonra, Armenia ordusunu MÖ 94 yilında Cappadocia'dan çıkarararak Euphrates (Fırat) nehrinin doğusuna çekilmeye zorlamış ve Ariobarzanes'i tahtına yeniden yerleştirmiştir (Telford, 2014, 72-74). Sulla, MÖ 93 yılında Roma'ya döndükten sonra, zaman içinde muhtemelen II. Tigranes'in de desteğiyle VI. Mithradates, MÖ 90 yılında Roma'da başlayan iç çatışmaları firsat bilerek Cappadocia'nın büyük bir kısmını ele geçirmiş ve muhtemelen Ariobarzanes yeniden tahtından edilmiştir(App. Mith. X.67). Sulla, MÖ 88 yılında consul olarak atandıktan sonra VI. Mithradates'in Küçük Asia topraklarının neredeyse tamamı ve hatta Kuzey Hellas bölgesi üzerindeki hakimiyetine son vermek için harekete geçmiş ve uzun süreli savaşlara girişmiştir. Roma ordusu Batı'da onunla meşgulken II. Tigranes Doğu'da topraklarını genişletmeye başlamıştır. II. Tigranes, Parth kralı II. Mithradates'in MÖ 88/7 yılında ölümünü firsat bilerek ülkesinin önemli bir kısmını ilhak etmeyi başarmıştır. Hükümranlık alanını, Mesopotamia'nın ötesinde Euphrates nehrini geçerek Syria ve güneyde Phoenikia'nın bazı kısımlarına kadar genişleterek zirveye 
ulaştırmıştır. 6 MÖ 83 yılında Antiokheia'ya davet edilmiş, kendisine iç siyasi çekişmelerle iyice zayıf düşmüş olan Seleukos hanedanlığının kraliyet tacı teklif edilmiştir (GurzadyanVardanyan, 2004, 4.6). MÖ 78/77 yılı civarında Cappadocia'nın tamamına hakim olmuştur (Strab. XII.2.9).

II. Tigranes, güç ve iktidarının doruğunda gümüş, bronz ve bakır sikkeler bastırmıştır (Foss, 1986; Nercessian, 2000; Bedoukian, 1978; Gurzadyan-Vardanyan, 2004, 4.6.). Ayrıca yeni bir başkent kurmaya karar vermiştir; çünkü eski başkenti Artaxata (Artashat) kuzeye doğru izole edilmiş çok uzak dağlık bir bölgede yer almaktaydı (Strab. XI.14.6). Hâkimiyet alanını güneye ve batıya doğru oldukça genişlettiğinden yeni, daha merkezde ve ana ticaret yolları üzerinde bir başkentin inşa edilmesini gerekli görmüştür (Foss, 1986, 32). Armenia'nın güney kesiminde Arzanene olarak bilinen bölge boyunca uzanan Tigris nehrine dökülen Garzan (Yanarsu) çayı üzerinde günümüzde yıkık durumda olan Tigranokerta kentini kurmuştur. Kendi adını verdiği bu kentte Armenia kraliyet tacını giymiştir (App. Mith. X.67). Plutarkhos'un aktarımına göre; kent büyüleyici ve görkemli bir şekilde topraktan yükselmekteydi, sarayları ve yapıları süslü donanıma sahipti, bunlara ilaveten krallarla rekabet eden sıradan ve üst düzey insanların adak olarak bağışladığı mal

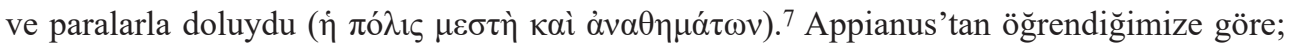
kentin surları çok yüksekti ${ }^{8}$ ve içte kalan alçak kesimlerinde atlar için ahırlar yer almaktaydı, kraliyet sarayı kentin dış bölgesindeydi ve etrafı içinde vahşi hayvan barınakları ve balık havuzları bulunan bir park tarafından çevrelenmişti, ayrıca saray yakınına güçlü bir kule kale de inşa edilmişti (App. Mith. XII.84).

II. Tigranes, Armenia'nın önde gelen soylularını mallarının hacz edileceği tehdidiyle muhtemelen Lucullus ile savaş sırasında inşası devam etmekte olan bu kentte iskâna zorlamıştı. ${ }^{9}$ Ayrıca, yukarıda belirttiğimiz, hâkimiyeti altına almış olduğu özellikle Parth topraklarından; Ninos, Arbela, Media Atropatene, Gordyene, Mesopotamia, Syria ve Phoenikia'dan pek çok yabancıyı göçe zorlayarak buraya yerleştirmişti. Strabon, genelde II. Tigranes'in talan ettiği on iki Hellen kentinden insanları, özelde MÖ 78/7 yılında Cappadocia’yı istila ettikten sonra

6 Eutr. Brev. VI.8. Önceden Parthlara devrettiği Armenia'daki 70 vadinin yanında Ninus ve Arbela topraklarını yağmalamış ve Mesopotamia'nın geri kalanı ile birlikte Atropatene ve Gordyene yöneticilerini kendisine boyun eğdirmiştir (Strab. XI.14.15). Ayrıca bkz. Plut. Luc. XXI.4-5; XXVI.1.

7 Plut. Luc. XXVI.2; Mabdesian, 1917, 452. Savaş sonunda Lucullus'un ele geçirdiği kent hazinesi 8.000 talanton paradan ve diğer bilinen değerli mallardan oluşmaktaydı. Lucullus 17.000 askerinin her birine genel yağmadan elde edilen gelirlerden 800 drakhme dağıtmıştı (Plut. Luc. XXIX.3). Brunt (1962, 77), Lucullus'un her bir askerine 950 denarii dağıttığını yazmaktadır. Yağma sonrasında dağıtılan sikkelerin bazısı hiç şüphesiz II. Tigranes tarafından bastırılan tetradrakhmeler olmalıydı (Foss, 1986, 32). Kentin zenginliği ve yağmalanmasıyla ilgili olarak ayrıca bkz. Polanski, 2013, 240.

8 Plinius (NH. VI.10), kentin yükseltilmiş bir yerde kurulduğunu bildirmektedir.

9 App.Mith. XII.84. Kralın kızkardeşi Tigranuhi'nin de kente yerleştirilmesiyle ilgili olarak Moses Khorenatsi'nin eserine (I.30) atıfta bulunulmaktadır (Thomson, 1978, 119). 
Mazaka (Kayseri) halkının tamamını kente getirdiğini bildirmektedir. ${ }^{10}$ Plutarkhos, göçe tabi tutulan Hellenlerin çoğunluğunun Kilikialı olduğuna vurgu yapmakla kalmayıp, kentleri yıkıldıktan sonra meskûnlarının zorla getirildiği diğer halklar arasında Adiabenoi, Assyrioi, Gordyenoi ve Kappadokialıları da saymaktadır (Plut. Luc. XXVI.1. Ayrıca bkz. Dio Cass. XXXVI.2.3-4). Bunların içinde II. Tigranes'in inşa etmiş olduğu tiyatro için tutsak aldığı pek çok Hellen drama oyuncusu da bulunmaktaydı (Plut. Luc. XXIX.4). Bütün bu aktarılanlar içinde dikkat çeken nokta Plutarkhos ve Appianus'un zorla göç ettirme konusunda Strabon ile hem fikir olmasıdır. Bu bağlamda II. Tigranes'in yeni kurduğu kente Hellenleri ve yerel bölgelerinden diğer etnik grupların nüfuslarını aktarmasının sebebinin özellikle yerel Hellen topluluklarla Hellen dostluğuna dayalı bağları güçlendirmeye dayandığı görüşünün gözden geçirilmesi gerekmektedir. ${ }^{11}$ Oysaki II. Tigranes, karşılıklı bir bağ oluşturmaktan ziyade kendisine karşı ayaklanmış veya itaat etmemiş ve yeniden ayaklanma ihtimali yükssek olan muhalif veya tehlikeli toplulukları dağıtarak kontrol altında tutma siyaseti doğrultusunda böyle bir karar almıştır. ${ }^{12}$ Kente dışarıdan getirilenlerin sayısının çok olması bu düşüncemizi desteklemektedir. Appianus, Cappadocia'dan sürülen insanların sayısını diğer halklarla birlikte yaklaşık 300.000 olarak vermektedir (App. Mith. X.67). Her ne kadar Strabon,

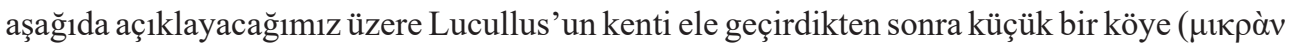
$\kappa \omega ́ \mu \eta v)$ dönüştürdüğünü öne sürse de, ${ }^{13}$ onun bu vurgusu kentin surlarının yıkımından daha çok kente zorla intikal ettirilen halkların geri gönderilmesiyle alâkalı olmalıdır (Cameron, 2014, 409-410). Kentin daha sonraki dönemlerde de varlığını güçlü bir şekilde devam

10 Savaştan sonra Mazaka halkının çoğunluğu geri dönmüştür (Strab. XI.14.15; XII.2.9; Pothecary, 2016, 211212).

11 Hatta II. Tigranes'in MÖ 83 yılı civarında Antiokheia'yı ele geçirdikten sonra kentin kadın tanrıçası Tykhe görselini üzerinde taşıyan sikke bastırması da karşılıklı bağa dayalı patronluk bağlamında değerlendirilmektedir. Bkz. Andrade, 2011, 124-125; Foss, 1986, 26 vd. Ayrıca bkz. Figür 1.

12 II. Tigranes, Parthlardan ele geçirdiği Mesopotamia’ya Cilicialı ve Cappadocialı Hellenleri ve komşu bölgelere ticari amaçlı olarak kullanabileceği Arap göçebeleri yerleştirmiştir. Dolayısıyla sadece Tigranokerta değil muhtemelen hazinesinin bir kısmını tuttuğu ve komutasını kardeşine devrettiği Nisibis (Nusaybin) ve hatta Antiokheia gibi önemli kentlere ve civarlarına da zorla bu halklar yerleştirilmiştir. Bkz. Plut. Luc. 21.4; Cass. Dio XXXVI.6.2; Plin. NH. VI.32; Sullivan, 1971, 56; Cameron, 2014, 407-408. Tigranokerta'ya nüfus intikali ile ilgili olarak ayrıca bkz. Avdoyan, 2006, 81-95. Diğer taraftan göçe tabi tutulan halkın kültürüne uygun şekilde hareket edilmesi gereğinin doğmuş olduğunun da burada vurgulanması gerekmektedir. Bu bağlamda Atina'dan pek çok Hellen tanrısının heykelinin Armenia tapınaklarına zenginlik katmak için getirildiği ve Attika sanat havası oluşturmak için Tigranokerta'da hatiplerin, müzisyenlerin, drama ve komedi tiyatro gruplarının ağırlandığı, bunun için bir Hellen tiyatrosu inşa edildiği, dolayısıyla kozmopolit bir kent oluşturulmaya çalışıldığı düşünülmektedir (Missirian, 1961, 334. Coyne, 1912, 610).

13 Strab. XI.14.15. Memnon ise (FGr Hist 434 38.6) ümidini yitiren komutanların kendi güvenlikleri için kenti Lucullus'a teslim ettiklerini bildirmektedir. 
ettirdiği anlaşılmaktadır. ${ }^{14}$

Tigranokerta savaşına giden süreci anlamak açısından öncelikle savaş öncesi gelişmeler üzerinde durulması ve bunların açıklanması gerekmektedir. Yukarıda da belirttiğimiz üzere Sulla, VI. Mithradates'e karşı yürütülen savaşta görevlendirilmiştir. MÖ 87 yılında Hellas'a ulaşmış, MÖ 86 yılında Khaironeia'da ve MÖ 85 yılında Orkhomenos’ta VI. Mithradates'i iki kez üst üste yenilgiye uğratmıştır. VI. Mithradates ile MÖ 85 yılında Dardanos'ta sözlü bir ateşkes antlaşması yapmış ancak içerideki düşmanlarının üstesinden gelmek için MÖ 84 yılında Roma'ya geri dönmek zorunda kalmıştır. Daha sonra VI. Mithradates, krallığının verasetini Roma’ya bırakan Bithynia kralı Nikomedes'in MÖ 75/74 yılında ölümü üzerine tekrar Bithynia ve Küçük Asia’yı işgal etme gayreti içine girmiştir. Roma senatosu, Cilicia Eyaleti'ni Lucius Licinius Lucullus'a, Bithynia'da işleri düzeltme görevini ise Marcus Aurelius Cotta'ya devretmiştir. Aynı zamanda her iki consule de VI. Mithradates'in peşinden gitmeye hazır olmaları talimatını vermiştir. Lucullus ve Cotta, MÖ 73 yılında güçlü bir ordu ve donanmayla ona karşı harekete geçmiştir. Ancak Cotta, Kalkhedon (Kadıköy) yakınında yenilgiye uğramıştır. Bu arada VI. Mithradates, Kyzikos kentini ele geçirmeye çalışmış, fakat Lucullus onu arkadan kuşatıp, ordusunun erzaklarının önünü keserek aç bırakmış ve nihayetinde MÖ 72 yılında Rhyndakos ve Granikos çatışmalarında ağır kayıplar verdirmiştir. VI. Mithradates denizde de bir seri yenilgiye uğradıktan sonra Pontos’a kadar geri çekilmiştir. Lucullus, MÖ 71 yılında Kabira yakınında gerçekleşen ikinci bir çatışmada, kralın seçilmiş 35.000 askerini katletmeyi başarmıştır. VI. Mithradates bunun sonucunda II. Tigranes'in Armenia bölgesine sığınmıştır ve burada muhtemelen II. Tigranes’in de gizli onayıyla bir

14 Lucullus'un Amisos kentinin yakılıp yıkılması, dolayısıyla talan edilmesi karşısında gözyaşlarına boğulduğu, ancak yine de muhtemelen saygınlığını yitirmemek için talandan sonra kenti restore etmeye çalıştığı öne sürülmektedir (Plut. Luc. XIX.4-6). Rey (2015, 232) çalışmasında, Lucullus’un Tigranokerta kenti yağmalandığında gözyaşlarını döktüğü dair yanlış bir bilgi vermektedir. Paetus ve Cn. D. Corbulo'nun Parthia kralı I. Vologaeses'in kardeşi ve Armenia kralı olan I. Tiridates'e karşı saldırıları sırasında kentin önemini korumaya devam ettiği görülmektedir. Corbulo'nun MS 58 yılında kenti Armenia soylusu Vadandus'un kellesini kuşatma altındaki kent surları içine ballista ile firlatılması gibi aşağılayıcı bir yöntemle ele geçirdiği ve Roma'da yetiştirilen VI. Tigranes'i tahta çıkardığı bildirilmektedir. Bkz. Frontin. strat. II.9.5; Ash, 2006, 369 vd. Ayrıca bkz. Carter, 2004, 372 vd.; Norris, 2005, 66-67. Tacitus (Ann. XV.4), kentin daha sonra MS 61 yılında Parthlar tarafından kuşatma altına alındığını ve bu tarihte görkemli surlara sahip olduğunu (urbem... magnitudine moenium validam) aktarmaktadır. Kentin MS 350'li yıllarda da görkemli olduğuna işaret eden deliller bulunmaktadır. MS IV. yüzyıl'da Armenia bölgesini anlatan ve bir Armenia kaynağı olan Buzandaran patmut'iwnk' (Epik Tarihler) başlıklı eserde (IV.24), Sasani kralı II. Şapur'un Armenia kralı II. Aršak (MS 350ca. 364/367) iktidarı sırasında Küçük Armenia bölgesini istila ettiği, pek çok kale ve tahkim edilmiş kalenin yanında Arzanene (Ałjnik') eyaletinde bulunan büyük Tigranakert kentini de yıktığından ve aynı zamanda kentte hıristiyan şehitleri için kilisenin kurulduğundan bahsedilmektedir. Bunun yanında MS V. yüzyıl Armenia bölgesi hakkında yazan Moses Khorenatsi'nin Armenialıların Tarihi adlı eserinde (III.26-28) II. Şapur'un kenti kuşatması ve ele geçirmesine değinilmektedir. Bunların yanında Roma imparatoru Heraklios'un Sasanilere karşı MS 622-628 yılları arasında düzenlediği sefer bağlamında kentten söz edilmektedir. MS VII. yüzyıl'da Sebeos (XXXVIII.125) tarafından ve MS XI. yüzyıl'da yazan Stepanos Taronetsi (Stepanos Asoghik) kroniğinde (II.4) de sözü edilmektedir (Marciak, 2016, 299-300; Cameron, 2014, 413). Diğer taraftan Geç Dönem antik kaynaklarında başka bir Tigranokerta kentine atıfta bulunulması ihtimali hakkında bkz. Cameron, 2014, 427-428. 
sene sekiz ay kaldığ 1 bildirilmektedir, nihayetinde II. Tigranes onu sarayında ağırlamayı kabul etmiş ve hatta 10.000 atlı askerle geriye Karadeniz'e göndermiştir (Memnon FGr Hist 434 38.1). Bu arada Lucullus, MÖ 70 yılı itibariyle Amastris (Amasra), Herakleia (Karadeniz Ereğlisi), Sinope (Sinop) ve Amisos (Samsun) gibi önemli kentlerin tamamını ele geçirmiş, talan ederek ağır vergilere tabi tutmuştur. Sinope'yi ele geçirdiğinde II. Tigranes ve VI. Mithradates'in güneyde Lykaonia ve Cilicia bölgelerini tehdit ettikleri haberini almıştır (Plut. Luc. XXIII.7). Bu tehditler üzerine Lucullus, VI. Mithradates'in kendisine teslim edilmesi için Appius Claudius'u elçi olarak göndermiş, ancak II. Tigranes kayınpederini teslim etmek gururuna dokunacağından bir mektup yazarak olumsuz cevap vermiştir. ${ }^{15}$ $\mathrm{Bu}$ tavrı Roma ile savaşı göze aldığı anlamına gelmektedir. II. Tigranes, büyük olasılıkla Armenia topografyasının zorlu ve kolaylıkla ele geçirilemez olmasına ve ayrıca Doğu ve Güneydoğu'daki müttefiklerinden alacağı desteğe güvenerek bu kararı almıştır.

Lucullus, VI. Mithradates'in teslim edilmemesini de firsat bilerek gizli ve ani bir baskınla inşa faaliyeti hala devam eden Tigranokerta kent savunmasını hazırlıksız yakalamak istemiş olmalıdır. Ayrıca Memnon, yukarıda da açıkladığımız üzere Tigranokerta kentinin refah ve zenginliğinin Lucullus ve askerlerinin ilgisini çektiğini ima etmektedir (Memnon FGr Hist 434 38.2). Onun yukarıda değindiğimiz ele geçirilen Karadeniz kentlerinde askerlerinin talan etmesine müsaade etmesi bu görüşü doğrulamaktadır. Bunların yanında Lucullus'un hem II. Tigranes hem de VI. Mithradates'e karşı zafer kazanması onun Roma'daki itibarını artıracaktır. Antik kaynaklar Lucullus'un çok geçmeden II. Tigranes'e karşı saldırıya geçtiği ve saldırının yönü hakkında hemfikirdir. Ordusuyla Cappadocia boyunca yürüyüşle Pers kraliyet yolu üzerinde Tomisa'da (Malatya yakınında) Yukarı Fırat nehrini geçtikten sonra Sophene bölgesi (muhtemelen modern Elazı̆̆-Maden-Ergani yolu üzerinden) üzerinden ilerlemiş, Fırat nehri geçildikten sonra uzun bir yürüyüşle Toros dağlarının eteklerindeki Tigranokerta kenti uzaktan görüş alanına girmiştir (Plut. Luc. XXIV.8; App. Mith. XII.84; Sall. Hist. IV.60). Plutarkhos'un iddiasına göre, bu sırada Phoenikia seferinden başkentine dönen II. Tigranes, Roma birliklerinin Armenia toprağında görüldüğü haberine inanmak istememiş ve hatta Lucullus'un Armenia'ya girdiğini bildiren ilk habercinin kafasını kestirmiştir. Ancak acı gerçekle karşılaştığında öncelikle komutanı Mithrobarzanes (Meruzhan/Meruzanes)'i Lucullus'a karşı göndermiş ve onun canlı getirilmesi emrini vermiştir (Plut. Luc. XXV.1-2). Böylelikle en azından düşmanın hareketlerini geciktirmeyi planlamaktadır. Plutarkhos, bu noktada şöyle devam etmektedir:

"[3] Lucullus...birbirinden ayrı düşen, düzensiz durumda bulunan ordusuna düşmanın saldırarak karmaşaya sokabileceğinden korkarak, bizzat kendisi ordugâhın kurulması işini üstlendi. Legatusu Sextilius'a, 1600 atlı ve toparlayabildiği kadar hafif ve ağır piyade ile birlikte, bütün askerlerin emin bir şekilde ordugâha yerleştirildiği bildirilinceye kadar

15 Memn. Peri. Her. XLVI.1-3; App. Mith. XII.83. Cicero (Leg. Man. 22-25) II. Tigranes'in bu zor anında VI. Mithradates'i kabul ettiğini ve her ikisinin birlikte hareket ederek Küçük Asia'daki halkı Romalılara karş1 ayaklandırdıklarını vurgulamaktadır. 
birliklerin başında düşmana yaklaşması ve orada beklemesi emri verildi. Zaten Sextilius da bunu yapmak istiyordu. Ancak ona cesurca saldıran Mithrobarzanes ile çatışmaya girmeye zorlandı. Mithrobarzanes akabinde savaşırken öldü, güçlerinin geri kalanı kaçmaya başladı ve çok azı dışında hepsi katledildi...[5] Tigranes, bunun üzerine inşa etmiş olduğu görkemli Tigranokerta kentini terk ederek Toroslara çekildi ve orada her yerden destek toplamaya başladı. Lucullus, ona hazırlanma firsatı vermedi. Murena'yı Tigranes'e katılmak amacıyla bir araya gelen güçleri püskürtmek ve önlerini kesmek, Sextilius'u da krala yaklaşmakta olan çok sayıda Arabı kontrol altında tutmak için tekrardan sefere gönderdi. [6] Sextilius, ordugâhlarını kurmakta olan Araplara baskın yaptı ve çoğunu katletti. Bu arada Tigranes'i sıkı takibe alan Murena'nın eline bir firsat geçti. Uzun sıra halinde ordusuyla engebeli arazi ve dar geçitten geçmekte olan kralın ordusuna saldırdı. Tigranes bütün yükünü bırakarak kaçtı. Armenialıların çoğu katledildi ve yakalandı.” (Plut. Luc. XXV.3-6).

Appianus, ek olarak Lucullus'a karşı gönderilen Mithrobarzanes'in 2.000 atlı birliğe sahip olduğunu, ancak Lucullus ile girdiği çatışmada onun ölmediğini ve kaçtığını belirtmektedir. Ayrıca II. Tigranes'in Tigranokerta savunmasını Mankaios'a bıraktı̆̆ını, eşini ve hazinesini yanına almayarak ordu toplamaya gittiğini; bunun üzerine Sextilius'un Mankaios'u Tigranokerta'da kapana sıkıştırdığını, surların dışındaki sarayı talan ettiğini ve hendek kazdırıp savaş makinalarıyla saldırıya devam ettiğini bildirmektedir. ${ }^{16}$

Hem Plutarkhos hem de Appianus'taki ortak nokta II. Tigranes'in asker toplamak ve müttefikleri ile bağlantı kurmak için geri çekilmesidir. Müttefiklerinin çoğu imparatorluğunun kuzey ve doğusunda yer aldığından, ${ }^{17}$ onun Armenia’nın esas nüfuz alanına geri çekilmiş olma ihtimali yüksektir. Bu arada Lucullus kuşatmaya destek vermek için geride kalan ordusuyla Tigranokerta üzerine yürümüştür (Plut. Luc. XXVI.1; App. Mith. XII.85; Memnon FGr Hist 434 38.5). II. Tigranes ise daha fazla asker ve müttefik topladıktan sonra Torosları aşmıştır ve Romalıların kuşatma altına aldıkları kente yüksekten baktığı öne sürülmektedir (Plut. Luc. XXVII.1). Halbûki II. Tigranes'in meydan savaş1 öncesindeki yenilgilerine rağmen büyük bir ordu toplayarak Tigranokerta'ya geri döndüğü önerisine şüpheyle yaklaşmak gerekmektedir. Aşağıda da tartışacağımız gibi, Armenia ordusunun Tigranokerta meydan savaşında asker sayısı üstünlüğünün abartılmaması gerekmektedir; çünkü Roma ordusu hali hazırda savaş öncesinde Armenia ordusunun öncü birliklerini yenilgiye uğratmış ve düşmanın kuzeyden ve güneyden destek toplamasını engellemede de başarılı olmuştur.

16 App. Mith. XII.84. Appianus, Mithrobarzanes'e karşı savaşan Roma birliğini Sextilius yerine Lucullus'un komuta ettiğini bildirmektedir. Murena'dan ve II. Tigranes'in dağlara kadar izlendiğinden bahsetmemektedir.

17 Armenialılar, Gordyenoi, Medes, Adiabene ülkesi kralları, Babylonia denizinden pek çok Arap topluluğu (muhtemelen Kharakene), Albanialılar ve Hazar denizi etrafından Iberialılar. Ayrıca Arakses nehri etrafinda yaşayan krala tabi olmayan halkların çoğu verilen yardımlar ve rüşvet aracılığı ile onun ordusuna katılmaya teşvik edilmişti (Plut. Luc. XXVI.4). 


\section{Asker Sayısı Meselesi}

Appianus'a göre; II. Tigranes Torosları ordusuyla geçtikten sonra güçlerini ikiye bölmüş, küçük bir grubu Tigranokerta kentini kuşatan Roma askerlerine, büyüğünü ise Lucullus'a karşı göndermiştir. VI. Mithradates ona elindeki üstün ağır zırhlı atlı birliklerini kullanarak Roma piyadelerini tahrik etme önerisinde bulunmuş ancak II. Tigranes bu tavsiyeyi göz ardı ederek Romalılara ön cepheden saldırmayı tercih etmiştir (App. Mith. XII.85). Bu tavsiye konusuna Plutarkhos da değinmektedir. VI. Mithradates destekçisi Taxiles ile birlikte israrla II. Tigranes'e ‘yenilmez' Roma ordusu karşısında meydan savaşına girişmemesi, bunun yerine atlı birlikleriyle düşmanın takviye güçlerinin önünü kesmesi tavsiyesinde bulunmuştur (Plut. Luc. XXVI.4). Buna rağmen II. Tigranes, yukarıda belirttiğimiz üzere hâkimiyeti altında bulunan pek çok halk ve devletten destek olarak elde ettiği ordusunun sayısal büyüklügüune güvendiğinden bu tavsiye ve önerilere kulak asmamıştır.

Plutarkhos ile devam edecek olursak; Lucullus'un mektupla senatoya bildirdiğine göre II. Tigranes'in ordusu şu unsurlardan oluşmaktadır: 20.000 okçu ve kargıcı; 17.000'i zırhlı 55.000 atlı birliği; bazıları cohors (lejyonun onda birlik bölüğü) bazıları da phalanx düzeninde sıralanmış 150.000 ağır piyade; sayıları 35.000’i bulan yol ve köprü inşaatçıları, nehir temizleyicileri, ormancılar ve ordunun diğer ihtiyaçlarını karşılayan idareciler (Plut. Luc. XXVI.6). Diğer taraftan Lucullus, meydan savaşı başlamadan hemen önce ordusunu ikiye bölmüştü. Murena'yı 6.000 piyade ile birlikte kenti kuşatması için bırakmış ve bu arada kendisi sayısı 10.000'i aşmayan ağır piyade birliği ve yaklaşık olarak sayıs1 1.000'e varan atlı birlik, kargıcı ve okçularla düşman üzerine yürümeye başlamıştı (Plut. Luc. XXVII.2). II. Tigranes ve etrafindakiler, Lucullus'un bu ordusu karşısında, ziyafet ve konseylerde şevke gelerek sayısal üstünlüklerinden dolayı savaşı kazanacaklarına dair güvenlerini pekiştirmekteydi. Bu arada VI. Mithradates'in kıskançlık yüzünden kralı büyük bir meydan zaferinden mahrum bırakma arzusuna kapıldığı görüşü hâkim olmuştu. Bu andan itibaren II. Tigranes, VI. Mithradates'i bile beklemeden zaferini paylaşmasın diye ordusunun tamamıyla ilerlemiş ve onun bütün Roma generalleri bir yana yalnızca Lucullus'u savaşmak için ciddiye aldığı söylentileri yayılmaya başlamıştı.

II. Tigranes, geniş bir ovada nehir boyunca ordugâhını kurduğunda Roma ordusu sayıca önemsiz gözükmüş ve hatta bu manzara kralın şakşakçıları için eğlence kaynağı olmuştu. Maiyetinden bazıları Romalılarla dalga geçmiş, diğerleri şakayla karışık ganimetler için hisse taksiminde bulunmuş ve hatta bu arada general ve müttefik krallardan her biri öne çıkarak fethetme görevinin sadece kendilerine verilmesi ve kralın sadece seyretmesi için yalvarmışlardı. II. Tigranes, Roma ordusunu gördüğünde bu nükte ve küçümseme ortamında arka planda kalmak istememiş ve şu meşhur sözünü söylemişti: "Ĕger elçi olarak geldilerse sayıları çok fazla; ĕger asker olarak geldilerse sayıları çok az” (Plut. Luc. XXVII.4). Plutarkhos'un bu sözleri daha çok kendi yorumu gibi durmaktadır. Ayrıca beklenenin tam 
tersine gerçekleşen savaş sonucunu Strabon'a da atıfta bulunarak alaya almakta ve barbar olarak gördüğü halkları aşağılamaktadır. Plutarkhos’un özellikle Strabon'a atfen kullandığı 'Romalıların barbar Armenialılara karşı savaşmak zorunda kaldıklarında kendilerinden utandıkları ve birbirlerine aşağılayıcı şekilde güldükleri’ yönündeki cümlesi dikkat çekicidir. Ayrıca Armenia tarafında 100.000'den fazla düşman piyadesinin yok edildiğini ve atlı birliklerinden çok azının kaçmayı başardığını aktarmaktadır. İddiasına göre, Romalıların sadece 100 askeri yaralanmış ve 5'i ölmüştür. Livius'a atfen Romalıların bu savaşa kadar hiçbir zaman bu kadar az sayıda askerle savaşmadıklarını vurgulamaktadır; çünkü muzaffer Roma ordusu sayı olarak düşmanının yirmide biri bile değildir ve hatta daha azdır. ${ }^{18}$

Plutarkhos'un yukarıda bahsettiğimiz aktarımlarında barbarlara karşı önyargılı tutumunun yansımalarına şahit olmaktayız. İlgili metinde dikkatimizi çeken ilk nokta II. Tigranes'in VI. Mithradates ve Taxiles'in tavsiyesini dinlememesi meselesidir. En başta Plutarkhos'un barbar olarak gördüğü düşman ordusu içinde böyle bir tavsiyede bulunulduğunu nasıl ve nereden öğrendiğini anlamak zordur. İddiasına göre, VI. Mithradates II. Tigranes'in kesin olarak gerçekleşeceği düşünülen zaferini önceden kıskandığından dolayı onun böyle bir tavsiyede bulunduğunu düşünenler olmuştur. Ayrıca konuyla ilgili aktarımda bulunan antik yazarlar arasında sadece Plutarkhos, VI. Mithradates Kabira savaşından sonra II. Tigranes'e sığındığında kendisine soğuk ve ilgisiz davranıldığını söyleme gereği duymuştur. O büyük olasılıkla bilinçli olarak her ikisi arasında önceden bir soğukluk oluştuğunu vurgulamakta ve savaş sırasında gerçekleştiğini iddia ettiği kıskançlık duygusuyla da bu iddiasını pekiştirmektedir. Dolayısıyla Plutarkhos'un buradaki anlatımı, II. Tigranes'in ordusunun büyüklüğüne dayalı kibrini ve bu kibrinden kaynaklı doğrudan meydan savaşına girme niyetini öne çıkarmak için uydurulmuş olabilir. Aşağıda açıklayacağımız üzere, tavsiyede bulundukları iddia edilen VI. Mithradates ve Taxiles'in doğrudan meydan savaşında yer aldıklarına değinilmemesi de bu konudaki şüpheleri artırmaktadır.

Diğer taraftan VI. Mithradates'in, ezeli düşmanı Roma karşısında zafer kazanacak olan kayınpederini kıskanmasını anlamak zordur. Eğer gerçeği yansıtıyorsa, VI. Mithradates bilakis Romalılara karşı önceden yürüttüğü savaşlarda edindiği tecrübeden dolayı II. Tigranes mutlak bir zafer kazansın diye böyle bir stratejik tavsiyede bulunmuş olabilirdi. Plutarkhos muhtemelen VI. Mithradates ve ordusunun, daha önce Lucullus tarafindan Kyzikos’ta takviye ve destek güçlerinin önünün kesilmesinden, kırsal alanın tahrip edilerek söz konusu askerlerin aç bırakılmasından yenilgiye uğratıldığı bilgisine sahipti. Aslında yukarıda aktardığımız üzere hem Plutarkhos hem de Appianus Lucullus'un başarılı bir şekilde uyguladığg bu yöndeki taktiksel gelişmelere değinmektedir. Buna rağmen Plutarkhos, savaşın başarısız sonucunu II. Tigranes'in doğrudan meydan savaşına girişme kararına bağlamaktadır. Plutarkhos bununla

18 Plut. Luc. XXVIII.6-7. Strabon, Cappadocialıydı ve belki de II. Tigranes özellikle Cappadocialı Hellenleri zorla Tigranokerta kentine göç ettirdiğinden böyle bir cümle kurmuş olabilirdi. 
bir noktayı kasıtlı olarak öne çıkarmaktadır. Lucullus gibi meşhur bir general ve yenilmez Roma ordusu sadece bir taktikle yenilebilirdi. Oysaki II. Tigranes bu taktiği uygulama gereği duymadı, çünkü o ordusunun sayısal üstünlüğüne güvenmekteydi.

Plutarkhos, ayrıca II. Tigranes'in kibirine (hybrisine) vurgu yaparak Roma generalleri içinde sadece Lucullus'u ciddiye aldığını iddia etmektedir. ${ }^{19}$ Lucullus'u yüceltmek için aklına bir fikir gelmiş olmalıydı. Nesilden nesile aktarılacak olan bu hikâyede, II. Tigranes gibi bir barbarın ancak büyük bir orduya sahip olduğundan dolayı cesaretlenebileceği mesajını küçümseyici bir biçimde vermeye niyetlendi. II. Tigranes'in ordusunu kasıtlı olarak 260.000 gibi aşırı bir rakam olarak gösterdi. Plutarkhos'un yazılarında böylesine bilinçli sapmalara ve dolayısıyla uydurmalara rastlanmaktadır. O, barbar olarak adlandırdığı öteki halklara karşı düşmanca tavır besleyen bir pan-hellenist yazardır ve bu yönünü zaman zaman bazı yazılarında da yansıtmaktadır. Hatta yeri geldiğinde yabancı kültürleri ve tarihini öven Herodotos'a philobarbaros (barbarbar dostu) lakabını verdiği ve onu bu konuda suçlamak için "Herodotos'un Kötücüllüğü Üzerine” bir deneme eseri yazdığı bilinmektedir. Böyle bir yazarın barbar olarak ötekileştirdiği bir halkı ve kralını küçük düşürmek için rakamları abartma ihtimali yüksektir. Bütün bunların yanında, Roma ordusunun kendisinden yirmi ve hatta daha fazla katta olduğu iddia edilen bir barbar ordusuna karşı muzaffer olarak gösterilmesi bir propaganda aracı olmalıdır. Böylesine bir propagandayla sadece savaşı yürüten Lucullus'un Roma' daki prestiji ve saygınlığı artırılmakla kalınmayacak aynı zamanda Roma halkı için moral kaynağı olacak ve uzak olan Asia eyaletinde yürütülen zorlu savaşa destek olunması sağlanacaktır. Bu bağlamda Plutarkhos'un, Lucullus'un Roma senatosuna birkaç kez gönderdiği ve büyük olasılıkla kendi zaferlerini abartılı gösteren mektuplardan faydalandığı görülmektedir. Yukarıda değindiğimiz üzere, Lucullus'un senatoyu savaşla ilgili olarak bilgilendirdiği mektupta Armenia ordusunun sayısını bilerek çarpıtmış olma ihtimali yüksektir. ${ }^{20}$ Lucullus'un yakın dostu ve Plutarkhos'un kaynak olarak kullandığı Arkhias'ın da bunda etkisi olmalıdi.

Plutarkhos, 'Kralların ve Büyük Komutanların Söylemleri/Apophthegmata adlı deneme çalışmasında Lucullus'u ve zaferini yüceltmeye şöyle devam etmektedir: "Lucullus Armenia'da on bin zurhll piyade ve bin atl askerle, Tigranes ve 150.000 kişilik ordusuna karşı Ekim'in altısinda, önceden Scipio'nun ordusunun Kimbroi tarafindan yok edildiği ay ve günde savaşacaktı. Birisi ona Romalıların bu günden korktuklarını ve nefret ettiklerini söylediğinde; bunun üzerine o, kahramanca savaşalım ki, bugün Romalılar için kara ve şanssız bir gün olmaktan çıkıp neşeli bir festival gününe dönüşsün demiştir. Askerleri zırhlarını parçalamak öldürmekten daha zor olduğundan en çok onların [Armenialıların]

19 II. Tigranes'in kibri konusunda ayrica bkz. Mulroy, 1988, 161.

20 Lucullus, bir başka mektubunda tamamen boyunduruk altına alındığını söyleyerek II. Tigranes'e karşı elde ettiği başarılarını abartmaya meyilli olduğu anlaşılmaktadır (Plut. Luc. XXXV.5). 
zırhl süvarilerinden korkmaktayd, ancak o askerlerini daha cesaretli olmaya davet etti. Illk önce bir tepenin başına geldi ve barbarların karmaşa içinde olduklarını anlayınca, dost askerlerim gün bizimdir dedi. Kimse karşısına çıkmayınca takip etti ve 5 Romalı kaybına karşı 100.000'den fazla [düşmanını] katletti." (Plut. Mor. 203 A-B. Ayrıca bkz. Plut. Luc. XXVII.6; Cam. XIX.7). Plutarkhos, bu metninde ilginç bir şekilde II. Tigranes'in sadece 150.000 ağır piyadesine atıfta bulunmaktadır. Kralın iddia edilen 55.000 süvarisinden söz etme gereği bile duymamaktadır. Ona göre, Lucullus'un sayısal zaafına rağmen kendine olan güveni tamdır ve hatta Romalıların daha önceden savaş kaybettikleri uğursuz bir günde savaşmayı tercih ettiğini iddia etmektedir. Sözümona gıpta ile bakılacak Lucullus, bu uğursuz günü Roma adına kazanılan zaferle mutlu bir güne çevirmiştir. Bu propagandayla daha önceden MÖ 105 yılında Scipio'nun Kimbroi karşısında yenilgiye uğratıldığı kara ve uğursuz gün, Lucullus'un zaferinin kutlanacağı neşeli bir festival günüyle unutturulmaya, dolayısıyla tarih sayfasında arka plana atılmaya çalışılmaktadır. Plutarkhos bu propaganda amacına ulaşmıştır; çünkü benzer sözler Appianus ve ondan sonra yazan Memnon tarafından da tekrar edilmektedir (Ayrıca bkz. Cass. Dio XXXVI.1b 2, fragmanlı).

Appianus, asker sayısı konusunda Plutarkhos'unkine benzer ancak daha kısa bir açıklamada bulunmaktadır. Plutarkhos, II. Tigranes'in ordusunda okçu, kargıcı ve istihkâm birliklerinin de dâhil olduğu toplam piyade sayısını 208.000 olarak verirken, Appianus sayıyı 250.000'e çıkarmaktadır. Atlı birlik sayısını ise 5.000 az göstermektedir. Appianus, II. Tigranes'in savaş sırasındaki başarısına da değinmekte, 6.000 atlı birlikle Roma ordusu kuşatma hattının yarılarak kurtarma operasyonu yapıldığına işaret etmektedir. II. Tigranes'in ordusunda ayrıca yük arabaları ve kent içinde Mankaios'a destek veren Hellen paralı askerler bulunmaktaydı. Diğer taraftan, Lucullus'un asker sayısına dair Plutarkhos'unki ile aynı rakamı vermektedir. ${ }^{21}$ Ayrıca ek olarak 1.000 askerden oluşan süvari, kargıcı ve okçulardan 500'ünün atlı olduğunu öğrenmekteyiz (App. Mith. XII.85).

Halbûki satır aralarından da anlaşılacağı üzere Lucullus'un asker sayısı gerçekte daha fazla olmalıdır. Appianus, Lucullus'un savaş öncesi yürüyüşüyle ilgili şu sözleri sarfetmektedir: “...Fırat nehrini geçti ve topraklarından geçtiği ancak savaşmak istemeyen veya Lucullus ile Tigranes arasındaki çatışmada taraf tutarak sıkıntılara maruz kalmak istemeyen barbarlardan sadece gerekli erzaklarını sağlamalarını rica etti..." (App. Mith. XII.84). Bu cümleden gerekli erzak sağlamayan yabancıların veya barbarların yardımcı birliklerle ona destek vermiş olabileceği ima edilmektedir. Lucullus'un Küçük Asia seferine başlaması sırasında emrine verilen lejyon sayısı bu öngörüyü doğrulamaktadır. Appianus'a göre, Lucullus VI. Mithradates'e karşı ilk seferinde Roma'dan sadece bir lejyonla, yani yaklaşık 6.000 ağır piyadeyle harekete geçmişti. Sonrasında önceden Fimbria komutasındaki iki lejyonu da emri altına almış ve bu arada 'iki lejyon daha' kendisine katılarak 30.000

21 İki lejyon ve 1.000 atlıdan oluşan yaklaşık 11.000 asker (Plut. Luc. XXVII.2). 
piyade ve 1.600 süvari asker sayısına ulaşmıştır (App. Mith. XI.72. Plut. Luc. VIII.5: 2.500 atlı asker sayısı verilmektedir). Plutarkhos'a göre Lucullus ilk lejyonu kendisi toplamış ve Küçük Asia'ya ulaştığında sadece Fimbria'nın birlikleri değil aynı zamanda bölgedeki diğer Roma güçleri de kendisine katılmıştır (Plut. Luc. VII.1-2). Appianus, 'iki fazlası eklendi' dediğinde, bu söz muhtemelen yerel olarak kayıt altına alınan iki lejyona atfen kullanılmaktadır; çünkü bu dönemde yereller ve hatta vatandaş olmayanlar bile ciddiyetle askere alınmaya başlanmıştı. Pek çok Romalı ve İtalyan da intikam amaçlı olarak Lucullus'a destek vermiş olmalıydı; çünkü VI. Mithradates MÖ 88 yılında Küçük Asia'da 80.000 Romalı ve İtalyan'ı katletmişti. Yukarıda belirtildiği gibi, II. Tigranes özellikle Cappadocia ve Cilicia'da pek çok topluluğu hâkimiyeti altına almış ve bunların önemli bir kısmını, zorla yerlerinden etmişti. Bu baskılara maruz kalmış olan Hellen ve diğer yabancı topluluklar da intikam duygusuyla Roma ordusuna doğrudan destek vermiş olmalıydı. Strabon (XII.2.1), Cappadocialıların Romalılara VI. Mithradates'e karşı yürüttüğü savaşta yardım ettiklerini bildirmektedir. Yerel Bithynialı atlı birlikler Galatialılar ve Pontoslu okçuların da ona destek verdikleri görülmektedir. ${ }^{22}$ Aslında Lucullus'un kendisi de, savaşı yürütmedeki başarısının Roma askerlerinden çok yerel askeri güçlere dayandığını senatoya yazdığı mektupta dile getirmektedir (Plut. Luc. XIII.4).

Lucullus emrindeki lejyon sayısını yediye çıkarsa da, bunların hepsi Tigranokerta savaşında görev almamıştır. Meydan savaşı sırasında iki önemli lejyon, birisi yakınında olmak üzere başka yerlerde görev yapmaktaydı. Sornatius'un komutası altındaki ilki, Pontos'da VI. Mithradates'in yokluğunda bölgeyi elinde tutmaya çalışmaktaydı (Plut. Luc. XXIV.1). Diğeri ise Murena'nın komutasında Tigranokerta'yı kuşatan lejyondu (Plut. Luc. XXVII.2). İlk kuşatmayı başlatan Sextilius'un asker sayısının 6.000 civarında, yani bir lejyondan oluşması mümkündür; çünkü Lucullus, meydan savaşından önce 6.000 askerini kuşatmayı devam ettirmek için Murena'nın komutası altında bırakmıştı. Lucullus'un bu kadar büyük bir güçle geldiği söylenen II. Tigranes’e karşı askerlerinin önemli bir kısmını, neredeyse yarısını kalenin kuşatmasında bırakması büyük bir cesaret örneğidir. ${ }^{23}$ Ya da Roma ordusunun aslında bildirilenden çok daha fazla olma ihtimalini gözler önüne sermektedir. Kuşatmayı

22 Lucullus'un ordusundaki Trakyalı ve Galyalı atlı birliklerinin savaşta etkin rol oynadıkları vurgulanmaktadır (Plut. Luc. XXVIII.2). Lucullus'un ordusundaki Makedonialı atlı birlikler için ayrıca bkz. Frontin. Strat. II.7.8. Özellikle Trakyalı birliklerin çok cesur saldırılar düzenlediğine işaret edilmektedir (Memnon FGr Hist 434 38.3). Bu birlikler arasında muhtemelen Avrupalı Trakyalılardan daha çok yerel Bithynialılar bulunmaktaydı. Bunların yanında Galatia kralı Deiotaros, daha önceden bağımsız olarak VI. Mithradates'in güçlerine karşı savaşmış (App. Mith. XI.75) ve Lucullus yürütülen savaşın bir noktasında erzak taşıtmak için 30.000 Galatialı hamal kullanmıştı (Plut. Luc. XIV.1). Plutarkhos’un meydan savaşı sırasında sözünü ettiği okçuların (Plut. Luc. XXVII.2) da Pontoslu olma ihtimali bulunmaktadır; çünkü VI. Mithradates'in oğlu ve Kırım Bosphoros Krallığı'nı elinde tutan Makhares çatışmadan önce hâlihazırda Roma müttefiki olarak kabul görme ricasında bulunmuştu (Plut. Luc. XXIV.1).

23 Plutarkhos'un bu olayı, Lucullus'un Amisos'un kuşatması esnasında Murena'yı burada iki lejyonla kuşatmayı devam ettirmesi ve kendisinin diğer üçüyle birlike Kabira toprağına sefer düzenlemesiyle karıştırıyor olabilir (Phlegon FGr Hist 257 12.10). 
gerçekleştiren dişında çevredeki kentleri talan için gönderilen muhtemelen bir diğer lejyondan daha bahsedilmektedir (Memnon FGr Hist 434 38.1). Plutarkhos ve Appianus'un verdiği rakamlar büyük olasılıkla sadece Lucullus'un komutası altındaki askerlerdir. Bütün bunlara Lucullus'un emrinde savaşan Fannius'un birlikleri de eklenmelidir. ${ }^{24}$ Bütün bu değerlendirmeler sonucunda Lucullus'un emrinde savaşa katılan lejyon sayısının daha fazla, en az üç veya dört olma ihtimali yüksektir.

Lucullus'un lejyon ordusu dışındaki yardımcı güçlerinin sayısını tam olarak tespit etmek daha zordur. Normal şartlarda Hispania'da olduğu gibi lejyoner sayısının yardımcı kuvvetlerle rekabet etmesi gerekirdi. Ancak Lucullus'un emrindeki atlı birliklerin VI. Mithradates'inkine oranla daha az nitelikli ${ }^{25}$ ve en fazla atlı asker sayısının 1.000 'den daha az olduğu bildirilmektedir (Plut. Luc. XXVII.2). Bu rakam, iddia edilen iki lejyondaki asker sayısının onda biridir ve mantıklı gözükmemektedir. Plutarkhos ve Appianus'un bunların içine Trakyalı ve Galyalı atlı birlikleri ekleyip eklemediği kesin değildir. Yine de en kötü şartlar altında bütün yardımcı birliklerin sayısının lejyonerlerinkinin yarısı ve hatta daha fazlası olması beklenmelidir.

Eutropius ve Festus, her ne kadar yine bilinçli olarak II. Tigranes'in asker sayısını fazlasıyla abartsalar da, Roma ordusunun asker sayısı hakkında daha mantıklı bilgi vermektedir. Eutropius, Lucullus'un Armenia'nın en görkemli kenti Tigranokerta'yı almayı başardığını söylemekte ve şöyle devam etmektedir: “Ona [Lucullus'a] karşı 600.000 zırhlı atl ve 100.000 okçu ve diğer birliklerle ilerleyen kralı [Tigranes'i], sadece 18.000 kişilik bir güçle tamamen mağlup etti ve Armenia ülkesinin büyük bir kısmını yıktı geçti." (Eutr. Brev. VI.9). Festus ise kısaca şöyle özetlemektedir: “Lucius Lucullus Pontos'un yönetimini kaybeden Mithradates 'i Armenia'ya kadar takip etti. Aynı şahıs 18.000 Romalı askerle, 7.000 zırhlı atl ve 2.000 okçuya sahip Armenia kralı Tigranes' $i$ yenilgiye uğratt. Armenia'nın en büyük kenti Tigranokerta'yı ele geçirdi." (Fest. Brev. XV.3). Bu metinde özellikle dikkati çeken nokta, eğer eseri kopyalama sırasında yanlışlıkla yazılmamışsa, II. Tigranes'in asıl ordusunun sadece 7.000 zırhlı atlı ve 2.000 okçudan oluştuğunun kaydedilmesidir. ${ }^{26}$ Bunun Eutropius'un verdiği toplamda 700.000 asker rakamıla arasındaki uçurum çok

24 Sornatius Barba'nın yanında Gaius Valerius Triarius ve Marcus Fabius Hadrianus, geride bırakılan bölgelerin kontrolü için Karadeniz'de bırakılmıştır. Son ikisi, özellikle Triarius Zela’ya yaklaşık 5 km. mesafede Sotion Dağı/Tepesi'nde MÖ 67 yılında VI. Mithradates'in geri dönmesiyle ağır bir yenilgiye uğratılmıştır. Savaş ve savaşla ilgili antik kaynaklar için bkz. Arslan, 2007, 425-429. Buna rağmen Triarius'un Tigranokerta savaşı sırasında Triarius'un nerede görev yaptığı tam olarak bilinmemektedir. Diğer taraftan Lucullus'un emrinde Lucius Fannius'un da görev yaptığını öğrenmekteyiz (Cass. Dio XXXVI.8.2). Lucullus'un emrinde Kabira savaşı sırasında Pomponius adında muhtemelen esir alınan bir atlı birlik komutanı daha olduğu kaydedilmektedir (Plut. Luc. XV.2).

25 Daha önceden VI. Mithradates'e karşı savaş sırasında kullanılan bu söylem için bkz. App. Mith. XII.80; Plut. Luc. XV.3.

26 Wilcox (1986, 42-44), II. Tigranes'in kamalar, mızraklar veya oklara sahip metal halkalı zırhlarla donanmış birkaç bin ağır zırhlı süvari birliğine (kataphraktes) sahip olduğunu bildirmektedir. 
fazladır. Plutarkhos (260.000) ve Appianus'un (300.000) verdiği toplam rakamlar ise Eutropius'unkinin neredeyse yarısıdır ve yine inanılması çok güçtür. Açıkça görüldüğü üzere Eutropius'un verdiği rakamın bir yazım veya kopyalama hatası olduğu veya kendisi tarafından kasıtlı olarak abartıldığı kanaatindeyiz. Büyük olasılıkla asıl toplam rakam, aşağıda açıklayacağımız üzere, Tralleisli Phlegon tarafından verilen 70.000 idi. Muhtemelen Eutropius, İmparator Valens'in Perslere karşı yürüteceği savaşın arefesinde geçmişte küçük bir Roma ordusunun kendisinden kat kat üstün bir barbar ordusunu yenilgiye uğrattığını propaganda amacıyla uydurmuş, böylelikle halk ve askerler arasında savaş ruhu ile şevkini artırmayı arzulamıştır. Bir diğer nokta da Eutropius ve Festus'a göre Lucullus'un ordusunun toplamda 18.000 askerden oluşmuş olmasıdır. Bu rakam Plutarkhos ve Appianus'unkinden en az bir lejyon fazladır. Her ikisi Plutarkhos'un belirttiği Murena'nın emrindeki lejyonu da ekleme gereği duymuştur.

Frontinus ise (Strat. II.1.14), Lucullus'un 15.000'den daha fazla askere sahip olmadığını bildirmektedir. Armenia ordusunun sayısı hakkında ise kesin bir rakam vermemiştir. Belki de düşman ordusu hakkında verilen rakamlar ona da pek inandırıcı gelmemiş ve sadece çok kalabalık olduklarını vurgulamakla yetinmiştir. Plutarkhos, Lucullus'un Bosphoros'u elinde tutan VI. Mithradates'in oğlu Makhares ile antlaşma yaptıktan sonra Sornatius'u bir lejyonla Pontos'ta bıraktığını, 12.000 piyade ve 3.000 civarında atlı asker gücüyle II. Tigranes'e karşı harekete geçtiğini bildirmektedir ki (Plut. Luc. XXIV.1-2), bu rakam Frontinus'unki ile uyuşmaktadır. Buna rağmen Plutarkhos'un meydan savaşı sırasında verdiği toplam sayı 11.000 civarına inmektedir (Plut. Luc. XXVII.2). Muhtemelen bu rakama Murena'nın kentin kuşatması için kulladığı lejyonu eklememiştir. Plutarkhos doğrudan teyit etmese de, meydan savaşı öncesinde Lucullus'un emrindeki iki lejyona ilaveten Sextilius ve Murena'nın komutalarındaki diğer iki lejyon eklenebilir. Bütün bunlara bölgede VI. Mithradates ve II. Tigranes'e düşman olan diğer halkların desteğiyle oluşturulan yerel ittifak birlikleri de eklenmelidir. Muhtemelen Plutarkhos bunları dikkate almamıştır.

Kronolojik olarak bakıldığında da Plutarkhos'tan başlayarak Appianus ve Eutropius'un verdiği Armenia ve müttefik asker sayısı rakamlarının farklılıklar göstererek gittikçe arttığını görmekteyiz. Bu rakamların uydurma olma ihtimalı yüksektir. Zaten iddia edilen böylesine kalabalık bir orduyu beslemek çok zor olmalıydı. Bölgede zaman zaman yiyecek kıtlığı olmaktaydı ve Tigranokerta kuşatma altındaydı. Yukarıda açıkladığımız gibi Lucullus daha meydan savaşı gerçekleşmeden taktiksel olarak II. Tigranes'in erzaklarının ve hatta ona müttefiklerinden gelecek askeri desteğin önünün kesilmesi yönünde belli bir başarı elde etmişti. Armenia ordusunda sayıları 35.000'i bulan yol yapıcılarının, köprü inşaatçılarının, nehir temizleyicilerinin, ormancıların ve ordunun diğer ihtiyaçlarını karşılayan yöneticilerin bulunduğu açıklamasına da ihtiyatlı yaklaşmak gerekmektedir. Amacı fetih yapmaya değil açıkça meydan savaşı gerçekleştirmeye giden bir orduda böylesine büyük bir sayıda 
istihkâm birliğine gerek duyulmuş olmasına şüpheyle bakmak gerekir. Amaç düşmana korku salmaksa, hali hazırda iddia edilen asker sayısıyla düşmanın karşısında arka arkaya dizilip görkemli bir duruş sergilenerek de bu başarılabilirdi. Plutarkhos ve Appianus'un Armenia ordusunda görev yaptığı iddia edilen bu destek birliklerinin sayısını belki de kasıtlı olarak abartmaları veya uydurmaları söz konusudur; çünkü aşağıda açıklayacağımız üzere savaşın Lucullus lehine dönmesini bunların sebep olduğu karmaşa belirlemiştir. $\mathrm{Bu}$ senaryoya göre, Roma ordusu bir tepeden yük arabalarına ve birliklerine saldıracak, bunlar da diğer Armenia birlikleri üzerine baskı oluşturarak onları paniğe sevk edecek ve böylelikle Armenia ordusunun düzeni bozularak kaçmaya zorlanacaktı.

Diğer taraftan özellikle Küçük Asia'nın yerel Hellen tarihçileri konuyla ilgili, sayısal anlamda devletin veya ilişki içinde bulundukları belli bir şahıs veya grubun resmi propagandasını yapmak yerine, daha tarafsız rakamlar vermeyi tercih etmişlerdir. Herakleialı Memnon, daha makul bir rakam vererek II. Tigranes'in kuşatmayı kaldırmak ve düşmanı geri püskürtmek için 80.000 asker topladığını bildirmektedir (Memnon FGr Hist 434 38.4). Bunun yanında, Roma ordusunun savaştan önce üç koldan harekât düzenleyebilecek kadar önemli sayısal üstünlüğe sahip olduğunu da ima etmektedir (Memnon FGr Hist 434 38.2-3). Tralleisli Phlegon ise, meydan savaşını 6 Ekim'e tarihlendirmekte ve şöyle bildirmektedir: “Lucullus Amisos'u kuşatmaktayd, Murena'yı kuşatmayı devam etmesi için iki lejyonla bıraktı̆̆ında, kendisi diğer üçüyle birlikte Kabira topră̆ına sefer düzenledi ve burada kışlık ordugâhını kurdu. Aynı zamanda (H)adrianus'a Mithradates'e karşı savaş yapması emrini verdi ve o da yenildi... Tigranes ve Mithradates Olimpiyatların dördüncü yılında 40.000 kişilik piyade ve 30.000 kişilik süvari ordusu topladıktan sonra, bunlar Roma çatışma düzenine göre dizildiler ve Lucullus'a karşı savaştıktan sonra yenildiler; Tigranes 5.000 askeri ile birlikte farklı halklardan kalabalık bir grubu kaybetti ve çok sayıda esir verdi." (Phlegon FGr Hist 257 12.10). Görüldüğü üzere Memnon ve Phlegon'un II. Tigranes'in ordusunun sayısı için verdikleri rakam 80.000 civarıdır. Phlegon daha mantıklı ve inandırıcı bir şekilde II. Tigranes'in 5.000 kayıp ve Memnon'un da vurguladığı gibi (FGr Hist 434 38.2) çok sayıda tuksak verdiğini aktarmaktadır. Plutarkhos'un iddia ettiği gibi Armenia tarafında 100.000 'in üzerinde kayıp olması abartılı bir rakamdır. Hatta Romalıların sadece 5 kayıp ve 100 yaralı vermeleri hiç inandırıcı değildir. ${ }^{27}$ Appianus ise inandırıcılığını yitirmemek için, II. Tigranes'in ordusunun kayıpları konusunda bir sayı vermemekte ve sadece Romalıların uzun bir savaş alanı mesafesi boyunca önlerine gelen kim varsa hepsini katlettiği yorumunu yapmaktadır.

27 Yukarıda belirttiğimiz gibi (dipnot 20), Lucullus'un savaş bittiğinde askerlerine ganimet olarak dağıttı̆̆ toplam miktar 8.000 talanton ise ve her bir askere 800 drakhme dağıtıldığı düşünüldüğünde, bu veriler ganimet dağıtılan asker sayısını en fazla 800 civarında yapar. Diğer gelirlerde bu toplamdaki 8.000 talantona ilave edilerek hesap yapılsa da, bu durumda savaş bittiğinde Lucullus'un çok da fazla askerinin hayatta kalmadı̆̆ 1 yorumu çıkarılabilir. 
Phlegon'un Armenia ordusu için verdiği 40.000 piyade sayısı sadece Armenia değil diğer müttefiklerden kaydedilenler (Plut. Luc. XXVI.4) dikkate alındığında da güvenilebilir bir rakamdır. Onun verdiği 30.000 atlı asker sayısı biraz fazla gözükse de, Armenia'nın dağlık ve yüksek coğrafyası Avrasya steplerine yakın olduğundan ve Armenia ordusunun büyük bir kısmı atlı birliklerden oluştuğundan bu rakam da mantıklı kabul edilebilir. Pontos ve Armenia kralları Avrasya steplerinden pek çok atlı, özellikle atlı okçu birliği desteği alabilmekteydi. Meydan savaşından önce daha savaşçı oldukları düşünülen Hazar denizi civarından Iberialı mızraklı süvariler askere alınmıştı (Plut. Luc. XXXI.5). Savaş sonrasında Armenia ordusuna yeni kaydedilen askerlerin üçte birinin atlı birlikleri oluşturduğu bildirilmektedir (App. Mith. XIII.87: farzedildiği kadarıyla 70.000 piyade ve onun yarısı kadar pek çok atlı). Benzer şekilde Cassius Dio (XXXVI.49.6), Armenia'da VI. Mithradates'in komutasında çoğunluğu Armenialılardan oluşan bir orduyu tarif ederek büyük bir kısmının atlı ve okçulardan oluştuğunu belirtmektedir. Ayrıca VI. Mithradates Kabira savaşından sonra II. Tigranes'in yanına 2.000 atlı birliği ile sığındığından (App. Mith. XII.82), bunlar ve VI. Mithradates'in komutanı Taxiles'in birliklerinin de (Plut. Luc. XXVI.3) II. Tigranes'in safında savaşa katıldığı görülmektedir. II. Tigranes'in ordusunda önemli sayıda, iddiaya göre atlı birliklerin yaklaşık üçte biri oranında atlı zırhlı birlikler de yer almaktaydı (Plut. Luc. XXVI.6; XXVII.6).

\section{Savaş Stratejisi ve Sonucu}

İlgili antik kaynaklar Roma ve Armenia askeri güçlerinin savaş sırasındaki hareketlerini detaylandırdığından bölge hakkında değerli topografik bilgiler sunmaktadır (Bkz. Plan 1). Plutarkhos ve Memnon'un ilk cümlelerinden savaşın Tigranokerta kentine oldukça yakın bir alanda gerçekleştiği anlaşılmaktadır (Plut. Luc. XXVII.1; Memnon FGr Hist 434 38.3). Özellikle, savaş sırasında Tigranokerta kentini savunmakta olan Mankaios'un kaleden Armenialıların yenilgiye uğradığını gördüğünü söylemesi bu tespiti desteklemektedir (App. Mith. XII.86. Ayrica bkz. Eckhardt, 1910).

Plutarkhos, Lucullus'un savaş stratejisi hakkında daha fazla bilgi vermektedir (Plut. Luc. XVII.4-XXVIII.6). Onun bu konudaki aktarımlarını özetlemek gerekirse; II. Tigranes müttefikleriyle geri dönerek Torosları aştığında kentin kuşatma altında olduğunu görerek bütün güçlerini harekete geçirmiştir. Birliklerini kent yakınlarında Nikephorios (Garzan/ Yanarsu $)^{28}$ çayının doğusunda, Lucullus ise nehrin batısındaki büyük ova boyunca ( $\pi \alpha \rho \grave{~}$

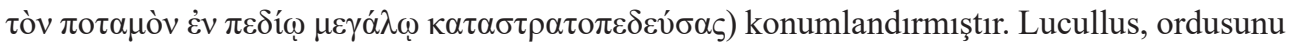
ikiye bölmüştür. Bir lejyonunu Murena'nın komutasında kent kuşatması için bırakırken, kendisi diğer bütün birlikleriyle düşmana karşı yönelmiştir. Lucullus bir noktada geri çekilme taktiği uygulamaya karar vermiştir. Birliklerini nehrin sığ olarak geçilebilecek en kolay yeri

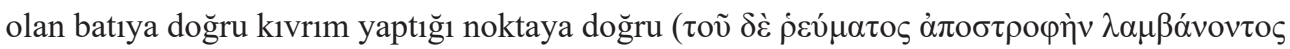

28 Tigranokerta kentinin lokalizasyonu Arzen olarak kabul edildiğinde, nehir Plinius (nat. VI.31.129) ve Tacitus (Ann. XV.4)'un da bahsettiği Nikephorios, günümüz adıyla Garzan/Arzan/Erzen/Yanarsu olmalıdır. 


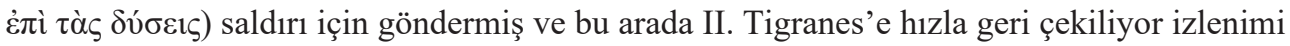
vermiştir. II. Tigranes, Roma birliklerinin geri çekildiğini zannetmiştir. Ancak Lucullus birliklerini aniden ve süratle nehrin sığ olarak geçilebilecek noktasına döndürerek saldırıya geçtiğinde, ${ }^{29}$ II. Tigranes buna inanamamış ve ordu birliklerini telaşla kolay ulaşılabilen üstü düz bir tepenin eteğinde çatışma düzenine sokmuştur. Kendisi ordunun merkezinde, Adiabenei kralı sol kanatta, Media kralı sağ kanatta yerini almıştır. Sağ kanadın önüne zırhlı atlı birliklerin büyük bir kısmı dizilmiştir. Lucullus en önde ve uzun mesafeli silahlar kullanan adamlarıyla kenetlenerek hızla ilerlemiş, böylelikle düşman okçularının etkili olabileceği boşluklar doldurulmuştur (Cowan-Hook, 2007, 42). Bu arada düşmanın en çok güvendiği zırhlı atlı birliklerin üstü geniş ve düz olan büyük bir tepenin eteklerine konuşlandığını ve bu tepenin düz olarak sadece dört stadionluk bir mesafede olduğunu gördüğünde, Trakyalı ve Galyalı atlı birliklerine yanlardan saldırmaları ve düşmanın tek silahı olan uzun mızraklarını kendi kısa kılıçlarıyla savuşturmaları emrini vermiştir. Ağır zırhlarının esnek olmaması yüzünden hareket kabiliyetleri de zayıf olan bu birlikler kapana sıkıştırılmıştır. Lucullus daha sonra yaklaşı 1.000 kişilik bir kuvvetle hızla ve ısrarla tepeye doğru ilerlemiş, tepeye ulaştıklarında askerlerini de düşmanın zırhlı atlı birliklere karşı yönlendirmiştir. Onlara kargılarını henüz fırlatmamaları ve yanlarına birer adam alarak düşmanın zırhlı atlı birlik askerlerinin tek açık yerleri olan kolları ve kalçalarına vurmaları emrini vermiştir. ${ }^{30} \mathrm{Bu}$ taktiği dahi uygulamaya gerek kalmamıştır; çünkü düşman üzerlerine gelen Romalıların çığlıklarını duyunca, savaşmayı beklemeden kendilerini ve atlarını bütün güçleriyle kendi piyadelerinin üzerine yönlendirmiş ve böylece tek bir yara veya kan akmadan iddiaya göre onbinlerce düşman katledilmiştir. ${ }^{31}$ Asker sıralarının yakınlığından ve derinliğinden dolayı düşman askerlerinin pek çoğu kaçmayı başaramamıştır. II. Tigranes ise kaçarken tacını oğluna vermiş, fakat oğlu kraliyet tacı ile yol almaya cesaret edemeyerek, onu en güvenilir kölesine emanet etmiştir. Bu köle de kraliyet tacı ile birlikte yakalanmıştır. ${ }^{32}$

29 Antik Arzen kenti, büyük alasılıkla kuzey-doğuya doğru yaklaşık 12 km. mesafede Balıklıgöl'ün bulunduğu Batman Kozluk İlçesi Oyuktaş Köyü Yeşilyurt (Golamasiya) mezrası karşısında Örensu'daki Zercel Kale bölgesine kadar uzanmaktaydı. Lucullus'un bu bölgeden saldırıya geçtiği öne sürülmektedir (Cameron, 2014, 425). Lucullus muhtemelen Tigranokerta kent hazinesinin tutulduğu kale olan Örensu'da Zercel Kale/ Aphoumon bölgesinden nehrin batıya doğru kıvrım yaptığı ve Arzen kent kalıntılarının da uzandığı aşağısı boyunca ilerleyerek geri çekiliyor izlenimi vermiştir. Bunun sonucunda zafer kazandığını düşünen düşman birlikleri öne ilerleyerek saflarını dağıtmıştır. Lucullus, sonrasında ani bir hareket yaparak daha güneyde nehrin sığ olduğu kısımdan geçerek II. Tigranes ve ordusunu Bozhöyük tepesi yakınlarında arkadan kuşatarak saldırmıştır. Bozhöyük Assur kaynaklarında Kullimeri, Bizans kaynaklarında Khlomaron olarak geçen ve Ptolemaios'un sözünü ettiği Cholimma olabilir. İsimlendirmeyle ilgili olarak bkz. Sinclair, 1996/7, 94-99.

30 Plutarkhos yukarıda da belirttiğimiz üzere diğer çalışmasında (Mor. 203A-B), Lucullus'un en çok II. Tigranes'in ordusundaki bu atlı zırhlı birliklerden çekindiği itirafında bulunmaktadır.

31 Frontinus (Strat. II.2.4), Plutarkhos'un sözlerini özetlemektedir.

32 Plut. Luc. XXVIII.6. Bu kral tacı daha sonra Lucullus'un triumphus seremonisinde teşhir edilmiştir (Plut. Luc. XXXVI.7). 
Appianus'a göre; Sextilius, surların dışındaki sarayı talan ettikten, kent ve kalenin etrafına hendek kazdırttıktan sonra savaş makinalarıyla Mankaios'u Tigranokerta'da kapana kıstırmıştır. Sextilius kuşatmaya devam ederken, II. Tigranes ordusuyla geri dönmüş ve atlı birliklerinden 6.000'ini Tigranokerta'ya göndermiştir. Bunlar Roma hattını yararak kaleye ulaşmış ve kralın cariyelerini getirmeyi başarmıştır. II. Tigranes, ordusunun geri kalanıyla Roma askerleri üzerine yürümüştür. Lucullus bu arada II. Tigranes'in arkasında iyi konumda bir tepe görmüştür. Önce düşmanı tahrik ederek onları üzerine çekmiş ve geri çekilmiştir. Böylelikle takibe kapılan barbarların düzenlerinin bozulmasını sağlamıştır. Bunun üzerine kendi piyade birliklerini tepeye doğru göndermiş ve gözlem altında tutulmayan bu tepeyi ele geçirmiştir. Lucullus düşmanın savaş kazanmış gibi kendisini takip ettiğini ve yüklerinin tamamıyla birlikte tepenin eteğinde bütün yönlerde dağıldığını gördüğünde, ilk önce yük taşıyıcılarına saldırmıştır. Yük arabaları gürültülü bir şekilde diğerleriyle çarpışmıştır. Bunlar karmaşa halinde kaçışarak kendi piyade birliklerinin, piyadelerde atlı birliklerin üzerine yürümüştür. Romalı atlı birlikler bozgunun nereden geldiğini anlayamayan düşman askerlerini takip ederek yok etmişlerdir. Büyük bir katliam ve yağma gerçekleşmiştir. Mankaios bu yenilgiye Tigranokerta'dan şahit olduğunda, kent savunmasında görev yapan Hellen paralı askerlerinin tamamını silahsızlandırmıştır. Karşılıklı güven sorunu doğmuş, paralı askerler de tutuklanacaklarından korkarak ayaklanmış, sağ ellerinde sopalarla ve sol ellerini elbiseleriyle sarıp kalkan olarak kullanarak savaşmış ve kulelerden bazısını ele geçirerek Roma askerlerini kentin içine almışlardır. ${ }^{33}$

Appianus, ek olarak Sextilius'un makinalarla ve hendek kazarak şehri kuşatmasına; daha inandırıcı olsun diye at arabalarının bozgundaki rolüne ve kentin Hellenlerin içeriden ayaklanması sonucu ele geçirildiğine değinmektedir. Özellikle Hellenlerin hiç silah kullanmadan kentin düşmesinde etkili olduğuna yönelik aktarımı inandırıcı gözükmemektedir. ${ }^{34}$ Gerçekte Mankaios güvenmediği Hellenleri kolaylıkla kentin dışına sürebilirdi. Cassius Dio'nun buraya zorla yerleştirilen halkın, özellikle Cilicialıların ayaklandığı ve bunların Roma askerlerini geceleyin içeri aldığını bildirmesi daha gerçekçi durmaktadır (Cass. Dio XXXVI.2.3). Aşağıda belirteceğimiz üzere Memnon ise, ne Hellenlere ne de ayaklanmalarına değinmekte, kentin zorda kalan komutanları tarafindan teslim edildiğini bildirmektedir.

Memnon'a göre; II. Tigranes savaş öncesinde öncü birliklerinin yenilgiye uğratılmasına rağmen kuşatma altındaki Tigranokerta'ya 80.000 askerden oluşan bir orduyla ulaşmış ve kentin yakınlarına ordugâhını kurmuştur. Bu arada II. Tigranes'in ilk gördüğü birliklerin

33 App. Mith. XII.84-86. Plutarkhos, büyük olasılıkla kasıtlı olarak II. Tigranes’in Romalı kuşatmacılara karşı gönderdiği askeri birlikten ve dolayısıyla Armenia ordusunun başarısından söz etme gereği duymamıştır.

34 Plutarkhos (Luc. XXIX.2) ayaklananlar için basitçe 'Hellenlerden' ( $\tau \tilde{\omega} v$ 'E $\lambda \lambda \eta ́ v \omega v)$ ibaresi kullanmaktadır. Oysaki söz ettiği üzere (Plut. Luc. XXVI.1), eğer aktarımı doğruysa normalde kentte bulunan diğer halkların da ayaklanmış olması gerekirdi. 
kuşatmayı önceden başlatan Sextilius'un birlikleri olduğu ve muhtemelen Lucullus'un komutasındaki ana ordunun henüz kent yakınlarına ulaşmadığı ima edilmektedir. Lucullus, ilk önce II. Tigranes' in cariyelerini ve pek çok değerli mallarını tuttuğu kenti bir lejyon birliği ile kuşatmış, diğerini çevredeki Armenia yerleşim birimlerine saldırması için göndermiştir. Pek çok Armenia yerleşim yerinin saldırı altında kaldığını gören II. Tigranes, VI. Mithradates’i geri çağırmış ve cariyelerinin tutulduğu kente kurtarılmaları için bir birlik göndermiştir. Kentteki okçular Roma birliklerinin mevzilerinden çıkmalarını engellemişler ve kaledekiler gece karanlığından faydalanarak cariyelerle birlikte değerli malları göndermeyi başarmıştır. Memnon, Plutarkhos ve Appianus'tan farklı olarak, Lucullus'un ilk önce Media kralının kontrolündeki düşmanın sağ kanadına saldırdığını ve bozguna uğrattığını bildirmektedir. Bu bozgun diğer birliklerin de kaçışmasına yol açmış ve Armenia ordusu dağılmıştır. II. Tigranes kalelerinden birine sığınmıştır. Lucullus daha sonra Tigranokerta'ya geri dönmüş ve kentteki generaller bütün ümitlerini kaybedip kendi güvenlikleri karşılığında kenti teslim edinceye kadar Trakyalılarla birlikte kenti kuşatmaya ve saldırmaya devam etmiştir. Dolayısıyla Memnon, Appianus'un aksine kentin, canlarının güvenliği için bizzat komutanları tarafından teslim edildiğini bildirmektedir. Yine de pek çok Armenialı katledilmiş ve büyük kısmı da esir alınmıştır (Memnon FGr Hist 434 38.2-6).

Yukarıda aktardığımız kaynaklara göre; VI. Mithradates meydan savaşında yer almamıştır. Memnon onun savaş sırasında acilen geri çağrıldığını bildirmektedir. Plutarkhos ise, Lucullus'un alışılagelmiş tedbir ve sabırla savaşa devam edeceğini düşündüğünden, onun II. Tigranes'e katılarak destek vermede geciktiğine vurgu yapmaktadır (Plut. Luc. XXIX.1). Lucullus, daha önce VI. Mithradates'e karşı yürüttüğü savaşta daha büyük bir zafer kazanmak için sabırla uzun gecikmelerle hareket etmiş ve yıpratma operasyonları sonucunda başarıya ulaşmıştı. Dolayısıyla, VI. Mithradates önceki tecrübelerinden hareket ederek Lucullus'un bu kadar hızlı davranıp savaşı sonlandıracağını tahmin etmemiştir. Lucullus, alışılagelmemiş biçimde hızlı manevralarıyla, daha kalabalık olduğundan hantal ve yönetilmesi zor durumdaki Armenia ordusuna düzene girme firsatı tanımadan onu yenilgiye uğratmayı başarmıştır (Frontin. Strat. II.1.14).

Gerçekte Tigranokerta savaşının, Lucullus'un kariyerinin geldiği seviyenin en üst noktalarından birisi olduğu öne sürülse de, ${ }^{35}$ Roma lehine kısa vadeli sonuçlarının çok fazla abartılmaması gerekmektedir. Lucullus'un emrinde altı yıl boyunca zor şartlar altında görev yapan Roma askerleri, Tigranokerta ve ayrıca diğer kentlerin de yağmalanmasından önemli miktarda birikim yaptıklarından bir an önce evlerine geri dönerek servetlerini harcama

35 Lucullus'un savaşta gösterdiği başarısı diğer generaller tarafından da takdir edilmiştir (Plut. Luc. XXVIII.8). II. Tigranes'in pek çok müttefiki savaş sonucunda Lucullus'un safına geçmiştir (Plut. Luc. XXIX.5; Dio Cass. XXXVI.2.5). 
arzusu içindeydi. ${ }^{36}$ Cicero, bu sırada Roma ordusundaki durumu şöyle özetlemektedir: Lucullus, "Tigranes'in krallığının bir kentini almasına ve bazı başarılı savaşlar yapmasına rağmen, Roma'dan çok uzakta olması ve dostlarından ayrı kalması nedenleriyle bizim ordumuzun morali iyi değildi [24] Şimdi daha fazlasını söyleyeceğim, çünkü bu hislerinin sonucu onlar düşman topraklarına daha fazla ilerlemektense hızlı bir şekilde evlerine dönmeye daha istekliydi..."37 Lucullus'un ele geçirdiği kentlerin talan edilmesine her ne kadar rıza göstermediği iddia edilse de, açgözlü (avaritia) bir komutan olarak hareket ettiği bilinmektedir. ${ }^{38}$ Pontos ve Armenia krallarına ve bunlara destek veren Hellen kentlerine karşı kazanılan zaferlerden elde edilen ganimetler gözünü iyice karartmıştır. Tigranokerta savaşından sonra artık askerlerinin ihtiyaçlarını karşılayan ve ekonomik motifle hareket eden bir komutan kimliğinin de ötesine geçmeye başlamıştır. Büyük İskender veya Homeros dönemi kahramanlarına özenerek neredeyse megalomania hissine kapılmıştır (Wylie, 1996, 117). Daha da büyük bir zafer kazanarak Roma’ya triumphus (zafer şöleni) ile dönme ve auctoritasını (itibarını) iyice güçlendirme hırsına kapılmıştır (Plut. Luc. XXX.2). Böylelikle consul görevine aday olabilmesinin de önü açılacaktır. Bu arzularını gerçekleştirmek için yeni hedefi Pontos'taki güçlerini de yanına çekerek Parthlara saldırmak olacaktır. Bu arada tutsak alınamayan II. Tigranes, komutanın tamamını VI. Mithradates'e devretmiştir (Memnon FGr Hist 434 38.7; App. Mith. XIII.87; Cass. Dio XXXVI.1.1, fragmanl1). Lucullus, ordusunun yaklaşan kış için karargâhını Gordyene'de kurmak için harekete geçmiş (Sall. Hist. 4.72; Syme, 1987, 54) ve ayrıca Sextilius'u sözümona Parthlarla antlaşma yapma, gerçekte ise keşif amaçlı olarak Parth sarayına göndermişstir (Cass. Dio XXXVI.3.2). Diğer taraftan VI. Mithradates, ordusuna katılan yeni birlikler ve ittifaklarla gücünü pekiştirmeye devam etmiştir (Cic. Leg. Man. 24). Kendisinin ve muhtemelen II. Tigranes'in yazdığı mektuplarla Parthlarla antlaşma yapmak istemiştir. Lucullus kendi safına geçen yerel hanedanlıklar aracılığg ile böyle bir girişim olduğunun haberini almış ve VI. Mithradates ile bir antlaşma yapılmaması konusunda tehditte bulunmuştur. Bu gelişmeler üzerine Parth kralı III. Phraates, muhtemelen iki tarafla da gizlice anlaşarak tarafsız kalmayı tercih etmiş ve onları birbirine

36 Plut. Luc. XXX.3-4; Wylie, 1994, 116. Dio Cassius (XXXVI.2.4), Romalıları kente alan Cilicialıların malları dışında her şeyin talan edildiğini ve ayrıca Lucullus'un emriyle önde gelen Armenialıların eşlerinin çoğuna dokunulmadığını bildirmektedir.

37 Cic. Leg. Man. 23-24. Roma ordusunun ilgisizliği ve isteksizliği konusunda ayrıca bkz. Eutr. Brev. VI.9.

38 Roma'daki tribunuslar ona kamu zararına kendisini zenginleştirmek için gereksiz yere savaşı uzatttığ suçlamasında bulunmuşlardır (Elmore, 1925, 431-432). 
düşürme politikası izlemiştir. ${ }^{39}$ Lucullus'un bu kararı alarak Parthlara karşı düzenleyeceği seferi ertelemesinde askerlerinin isteksizliği ve hatta sefere katılmayı reddetmelerinin de etkili olduğu anlaşılmaktadır.

Lucullus, her ne kadar senato bu aşamada onun ileri gittiğini düşünerek yedi yıl süren görevinin ardından verdiği yetkileri ilga eden bir karar alsa da, bu sefer II. Tigranes’i teslim olmaya zorlamak için Armenia ülkesinin merkezine saldırmaya karar vermiştir. Hem Plutarkhos (Luc. XXXI vd.) hem de Appianus (App. Mith. XII.86 vd.) onun II. Tigranes'in güçlerini geri çektiği eski başkenti Artaxata’yı ele geçirmeyi amaçladığını bildirmektedir; ancak ağır kış şartlarından ve erzak yetersizliğinden ordusunda genel bir ayaklanma başlamış ve kendi yakarışlarına rağmen seferini yarıda kesmek zorunda kalmıştır. ${ }^{40}$ Lucullus bunun üzerine güneye yönelmiş, Nisibis’i (Nusaybin) ele geçirdikten sonra Parthlara karşı bir sefere hazırlanırken yerini alması için halefi Pompeius MÖ 67 yılında gönderilmiştir (Eutr. Brev. VI.9; Fest. Brev. XV.3; Cic. Leg. Man. 26; Cass. Dio XXXVI.2.2; 16.3; Plut. Luc. XXXV.7). Yukarıda belirttiğimiz üzere, Kuzeyde Karadeniz'de ise VI. Mithradates ordusunu yeniden toparlamayı başarmış ve Lucullus'un komutanları Hadrianus ve Triarius'u MÖ 67 yılında Zela yakınlarında ağır bir yenilgiye uğratmayı başarmıştır. Pompeius, ertesi yıl VI. Mithradates’i Lykos savaşında yenilgiye uğratarak Kırım'a kaçmaya zorlamış ve çok geçmeden II. Tigranes teslim olmuştur. VI. Mithradates'in MÖ 63 yılında Kırım'da ya intihar ettiği ya da suikaste kurban gittiği bildirilmektedir. Pompeius’un bu zaferlerine rağmen, Armenia üzerindeki Parth nüfuzu artmaya devam etmiştir.

39 Antlaşma hakkında bkz. Plut. Luc. XXX.1; Memnon FGr Hist 434 38.8; Cass. Dio XXXVI.3.3; App. Mith. XIII. 87; Keaveney, 1981, 203-204; Simonetta, 2001, 82-83, 107; Schlude, 2009, 21-25. Lucullus'da Parthların kendi safına geçmesi için girişimde bulunmuştur (Cass. Dio XXXVI.3; App. Mith. XIII. 87; Ahlheid, 1988, 68-69). Tigranokerta Savaşı sonrası II. Tigranes'in damadı VI. Mithradates'in ağzından Roma'nın emperyalist politikalarına karşı Pompeius Trogus’un yanı sıra (Iust. XXXVIII.4-7) Sallustius (Hist. IV.67.1-4) gibi Romalı yazarların eleştiriler yöneltmesi ve bu bağlamda VI. Mithradates'in mektup göndererek Roma'ya karş1 Parthlardan yardım talep etmesi ve talebin sonuçsuz kalması konusunda ayrıca bkz. Adler 2006. Sallustius'un sunduğu delile göre, mektubu ileten elçilik heyeti MÖ 69 yılının sonbahar veya kış mevsiminde Parth kralı III. Phraates'e gönderilmiştir. Ancak heyetin savaştan önce mi yoksa sonra mı gönderildiği konusunda tartışmalar devam etmektedir. Mektupta Armenia Kralllığı'nın bütünlüğüne vurgu yapan ibarelerin yenilgiyi küçük gösterme niyetine binaen bilinçli ve abartılı bir şekilde sunulduğu ve aynı zamanda II. Tigranes'in sorunlu toprakları Parthlara devredebileceği imtiyazı da önerilerek Parth kralının desteğini kazanma arzusunun pekiştirildiği görüşlerine dayanılarak mektubun savaştan sonra gönderildiği savı için bkz. Schlude, 2009, 21-24. Sallustius, asıl arabulucunun VI. Mithradates olduğunu bildirmektedir. VI. Mithradates Parth kralının II. Tigranes ile arası olmadığını bilmektedir; çünkü II. Tigranes daha önceden Mesopotamia'nın bir kısmını Parthların elinden almıştır. VI. Mithradates, mektubunda II. Tigranes’i geri plana iterek bu yerlerin geri verilebileceğini ve bu bağlamda her türlü şartın kabul edilebileceğini iletmiştir. Ancak Parth kralı iki taraf arasındaki savaşa müdahil olmayarak II. Tigranes'in cezalandırılmasının önünü açmıştır. VI. Mithradates'in mektubunda bu konu üzerine tartışmalar için bkz. Raditsa, 1970, 61-68.

40 Plut. Luc. XXXII.3; Cass. Dio XXXVI.16.2. Diğer taraftan Lucullus'un bölgedeki komutanlığını ve savaşını devam ettirmek için VI. Tigranes'i ele geçirme niyetinde olmadığı iddia edilmektedir (Cass. Dio XXXVI.2.1). 


\section{Sonuç}

Tigranokerta meydan savaşı başlamadan önce önemli çatışmalar yaşanmıştır. II. Tigranes'in kendi ordusu ve müttefikleri büyük kayıplar vermiştir. Birincisinde, Lucullus Fırat nehrini geçip Tigranokerta'ya ilerlerken bölgedeki bazı Armenia kentlerine saldırılar düzenlemiş ve II. Tigranes tarafından kendisine karşı gönderilen Mithrobarzanes'i yenilgiye uğratmıştır. Lucullus ikinci ve üçüncü aşamada, önceden Kyzikos kuşatması sırasında VI. Mithradates'e karşı uyguladığg gibi, II. Tigranes'in ana ordusuna kuzeyden ve güneyden müttefik birliklerinin katılmasını̈ölemeyi amaçlamıştır. Bu bağlamda öncelikle düşmana karş1 casusluk faaliyetlerinde bulunmak için bu konuda tecrübeli olan Sextilius'un komutasındaki öncü birlikleri göndermiş, bu birlikler hem Tigranokerta'yı kuşatma altına almış hem de güneyden gelen Arap destek güçlerinin önünü başarıyla keserek onları yok etmiştir. Sonraki aşamada Murena, Torosların kuzeyinden ordu toplamaya giden II. Tigranes'in önünü muhtemelen engebeli ve dar Bitlis Geçidi’nde kesmiş, ordusuna ağır kayıplar verdirmiş ancak kral kaçmayı başarmıştır. Böylelikle hızlı hareket eden Lucullus, düşmanın öncü birliklerini yenmiş, erzak bölgelerini ve müttefiklerinden destek gelebilecek olan stratejik yerleri ele geçirmiştir. Buna rağmen II. Tigranes'in büyük bir ordu toplayarak geri döndüğü ve meydan savaşına giriştiği iddiaları doğruyu yansıtmamaktadır. Plutarkhos'un ve onu takiben Appianus'un ve sonrasında Eutropius'un Armenia ordusunun meydan savaşındaki sayısıyla ilgili olarak verdikleri rakamlar oldukça abartılıdır. Diğer taraftan Memnon, Phlegon ve Festus'un verdiği birbirine yakın olan rakamlar daha mantıklı gözükmektedir. Lucullus yanlısı kaynaklar kullanan Plutarkhos, II. Tigranes'in ordusunun çok kalabalık olduğunu ve buna rağmen az sayıda orduya sahip Lucullus karşısında küçük düşürücü bir şekilde başarısız olduğunu iddia eden bir senaryo hazırlamıştır. Aslında Eutropius, Frontinus ve diğer kaynaklar yorumlandığında, savaşa katılan Roma ordusunun sayısı da Plutarkhos'unkinin neredeyse iki katıdır. Lucullus çok uzun süreden beri emrinde hizmet ederek zaferler kazanmış tecrübeli ve düzenli birliklere sahipti. Bu tecrübeli birlikleriyle akıllı bir taktik uygulamıştır. Geri çekiliyor gibi yapmış, nispeten daha kalabalık olan düşman zafer kazandığını düşünerek saflarını öne doğru bozmuştur. Bu dağılmayı firsat bilerek beklenmedik şekilde ani bir saldırıya geçmiş, düşman ordusunun bel kemiği olan zırhlı atlı birlik askerlerini arkadan çevirerek yenilgiye uğratmıştır. Bunlar ve diğer atlı birlikler daha fazla karmaşaya yol açarak Armenia ordusunun dağılarak bozguna uğramasına yol açmıştır. Acilen toplanan yabancı müttefiklerinden oluşan daha tecrübesiz ve derleme birliklere sahip Armenia ordusu, ağır hareket ettiğinden eş güdümlü davranmayı başaramamış ve yenilgi kaçınılmaz olmuştur. 
Hakem Değerlendirmesi: Dış bağımsız.

Çıkar Çatışması: Yazar çıkar çatışması bildirmemiştir.

Finansal Destek: Yazar bu çalışma için finansal destek almadığını beyan etmiştir.

Peer-review: Externally peer-reviewed.

Conflict of Interest: The author has no conflict of interest to declare.

Grant Support: The author declared that this study has received no financial support.

\section{Kaynakça/References}

\section{Antik Kaynaklar ve Kısaltmalar}

App. (=Appianus, Rhomaika)

Mithr.

Cass. Dio

Appian's Roman History. Trans. H. White, vols. I-IV. Cambridge, Mass.London 1912-1913 (The Loeb Classical Library).

(= Cassius Dio, Rhomaika)

Roman History. Trans. E. Carry, vols. I-IX. London 1914-1927 (The Loeb Classical Library).

Cic. Leg. Man.

(= Cicero, Pro Manilia veya Oratio de Imperio Cn. Pompei)

The Speech on the Appointment of Gnaeus Pompeius. Trans. H. G. Hodge. London, New York 1927 (The Loeb Classical Library).

Marcus Tullius Cicero. Pompeius'un Yetisi Hakkında. Çev. Ü. F. Telatar. İstanbul 2002.

Eutr. Brev.

(= Eutropius, Breviarium ab Urbe Condita) The Breviarium ab Orbe

Condita of Eut ropius. Translated with an introduction and commentary by H. W. Bird. Liverpool 1993.

Fest. Brev.

(= Rufius Festus, Breviarium)

The Breviarium of Festus. A Critical Edition with Historical Commentary by Cf. J. W. Eadie. London 1967. http://attalus.org/translate/festus

Iust.

(= Marcus Iulianus Iustinus, M. Iuliani Iustini Epitoma Historiarium

Philippicarum Pompei Trogi)

Epitome of the Philippic History of Pompeius Trogus. Trans. by J. C.

Yardley. With introduction and explanatory notes by R. Develin. Atlanta 1994. http://www.attalus.org/info/justinus.html

Phlegon FGr Hist

(= Phlegon, Die Fragmente der griechischen Historiker)

F. Jacoby, Die Fragmente der griechischen Historiker. Vols. I-III. Berlin 1923-1958. Repr., Leiden 1950-1963.

Frontin. Strat.

(= Sextus Iulius Frontinus, Strategematon)

The Strategems and the Aqueducts of Rome. With an English translation by C. E. Bennett. Ed. M. B. McElwain. Lon-don/New York 1980 (The Loeb Classical Library). 
Memnon FGr Hist

Memn. Peri. Her.

Plin. $N H$.

Plut.

Cam.

Luc.

Plut. Mor.

Sall. Hist.

Strab.

Tac. Ann.
(= Memnon, Die Fragmente der griechischen Historiker Fragmenta)

F. Jacoby, Die Fragmente der griechischen Historiker. 3 vols. Berlin 19231958. Repr., Leiden 1950-1963.

Memnon. Trans. C. Müller. FGrHist. 434. http://www.attalus.org/translate/ memnon2.html

(= Memnon, Peri Herakleias)

Memnon. Herakleia Pontike Tarihi. Çev. Murat Arslan. İstanbul 2007.

(= G. Plinius Secundus, Naturalis Historia)

Pliny the Elder. The Natural History. Trans. J. Bostock, London 1855.

(= Plutarkhos, Camillus, Lucullus)

Plutarch. Plutarch's Lives. Trans. B. Perrin, vols. I-XI. London/New York 1959 (The Loeb Classical Library).

(= Plutarkhos, Moralia)

Plutarch's Moralia. Trans. F. C. Babbitt - W. C. Helmbold, vols. I-XIV, vol. III. London/New York 1928-1967 (The Loeb Classical Library).

http://www.attalus.org/translate/sayings3.html\#203

http://www.philaletheians.co.uk/study-notes/hellenic-and-hellenistic-papers/ plutarch-on-apophthegms-of-kings-and-great-commanders-tr.-hinton.pdf (= Sallustius, Historiae)

Sallust, The Histories. Trans. with introduction and commentary by P. McGushin, vol. I (1992), vol. II (1994). Oxford. http://www.attalus.org/ translate/sallust.html

(= Strabon, Geographika)

The Geography of Strabo. Ed. H. L. Jones, vols. I-VIII. Cambridge, Mass.London 1924 (The Loeb Classical Library).

(= Tacitus, Annales)

The Annals. Trans. by J. Jackson. Cambridge, Mass.- London 1969 (The

Loeb Classical Library)

\section{Modern Literatür}

Adler, E. (2006). Who's Anti-Roman? Sallust and Pompeius Trogus on Mithridates. The Classical Journal, 101 (4), 383-407.

Ahlheid, F. (1988). Oratorical Strategy in Sallust's Letter of Mithridates Reconsidered. Mnemosyne, 41 (1/2), $167-92$.

Andrade, N. (2011). Local authority and civic Hellenism: Tarcondimotus, Hierapolis-Castabala and the cult of Perasia. Anatolian Studies, 61, 123-132. 
Arslan, M. (2007). Mithradates VI Eupator: Romanın Büyük Düşmanı. İstanbul.

Ash, R. (2006). Following in the Footsteps of Lucullus? Tacitus' Characterisation of Corbulo. Arethusa, 39 (2), 355-375.

Avdoyan, L. (2006). Tigranocerta: the city 'built’ by Tigranes. R. G. Hovannisian (Ed.), Armenian Tigranakert/ Dijarbekir and Edessa/Urfa, Costa Mesa CA, 81-95.

Brunt, P. A. (1962). The Army and the Land in the Roman Revolution. The Journal of Roman Studies, 52 $(1 / 2), 69-86$.

Cameron, A. (1969). Review: The Breviarium of Festus, ed. J.W. Eadie. The Classical Review, 19 (3), $305-307$.

Cameron, H., Constructing A Borderland: Roman Imperial Geographic Writers On Mesopotamia From The $1^{\text {st }}$ to the $4^{\text {th }}$ Centuries BC (Phd Thesis). Ann Arbor: UMI 2014.

Carter, M. (2004). The "Lex Portorii" and the Armenian Campaign of Caesennius Paetus. Latomus, 63 (2), 370-379.

Comfort, A. (2017). Fortresses of the Tur Abdin and the confrontation between Rome and Persia. Anatolian Studies, 67, 181-229.

Cowan, R. - Hook, A. (2007). Roman Battle Tactics 109 BC - AD 313. Osprey Publishing.

Coyne, J. J. A. (1912), Hellenism and the Oriental Reaction. An Irish Quarterly Review, 1 (4), 599-620.

Demir, M. (2008). Antik Kaynakları Işı̆̆ında Tigranokerta Şehrinin Lokalizasyonu Meselesi. I. Uluslararası Batman ve Çevresi Tarih ve Kültür Sempozyumu, 15-17 Nisan, Batman, Cilt 1, 171-182.

Eckhardt, K. 1910. Die armenischen Feldzüge des Lukullus. II. Abschnitt. Das Kriegsjahr 69. Klio, 10, $72-115$.

Elmore, J. (1925), Caesar on the Causes of Mutiny. The Classical Journal, 20 (7), 430-432.

Foss, C. (1986). The Coinage of Tigranes the Great: Problems, Suggestions and a New Find. The Numismatic Chronicle (1966-), 146, 19-66.

Gerrish, J. (2012). Sallust's Histories and Triumviral Historiography (Phd Thesis). University of Pennsylvania.

Gurzadyan, V. G. - Vardanyan, R. (2004). Halley's comet of 87 BC on the Coins of Armenian King Tigranes?. Astronomy \& Geophysics, 45 (4), 4.6.

Holmes, T. R. (1917). Tigranokerta. The Journal of Roman Studies, 7, 120-138.

Keaveney, A. (1981). Roman Treaties with Parthia circa 95-circa 64 B.C. The American Journal of Philology, $102(2), 195-212$.

Mahdesian, A. (1917). Armenia, Her Culture and Aspirations. The Journal of Race Development, 7 (4), $448-466$.

Marciak, M. (2016). The site of Tigranokerta: status quaestionis. Acta Antiqua Academiae Scientiarum Hungaricae, 56 (3), 293-314.

Mayor, A. (2014). Common Cause Versus Rome: The Alliance between Mithradates VI of Pontus and Tigranes II of Armenia, 94-66 BC. M. M. Hülagu et al (Eds.), Tarihte Turkler ve Ermeniler: Ilkcă \& Ortacă̆, Ankara: Türk Tarih Kurumu, 99-119.

Misssirian, G. M. (1916). Armenia in the Agonies of National Crucifixion. The Journal of Race Development, 6 (3), 324-338.

Mulroy, D. (1988). The Early Career of P. Clodius Pulcher: A Re-examination of the Charges of Mutiny and Sacrilige. Transactions of the American Philological Association, 118, 155-178.

Nercessian, Y. T. (2000). Silver Coins of Tigranes II of Armenia. Armenian Numismatic Journal, 26, pts. $3 \& 4$, Group 3. 
Norris, S. (2005). Roman Strategies of Control: Terror and Intimidation (Phd Thesis). Alberta: University of Calgary.

Polanski, T. (2013). The Destruction of Cultural Heritage in the Kingdoms of Pontus and Kommagene during the Roman Conquest. Iran \& the Caucasus, 17 (3), 239-252.

Pothecary, S. (2016). A Road Trip with Strabo: Memory and Composition in the "Geography". Mnemosyne, 69 (2), 202-225.

Raditsa, L. F. (1970). A Historical Commentary to Sallust's Letter of Mithridates. Columbia University.

Rey, S. (2015). Roman tears and their impact: a questin of gender? Clio. Women, Gender and History, 41, "Real socialism" and the challenge of gender, Trans. by M. Rothstein, 225-245.

Schlude, J. M. (2009). Rome, Parthia, and Empire: The First Century of Roman-Parthian Relations (Yayımlanmamış Doktora Tezi). Berkeley: University of California.

Simonetta, A. M. (2001). A Proposed Revision of the Attributions of the Parthian Coins Struck during the So-called 'Dark Age' and Its Historical Significance. East and West, 51 (1/2), 69-108.

Sinclair, T. A. (1989). Eastern Turkey: An Architectural and Archaeological Survey III, London.

(1995). The site of Tigranocerta, I. Revue des Études Arméniennes, 25, 183-254. https://doi. org/10.2143/REA.25.0.2003781

(1996-1997). The site of Tigranocerta, II. Revue des Études Arméniennes, 26, 51-118. https://doi.org/10.2143/REA.26.0.2003745

Sullivan, R. D. (1971). Some Dynastic Answers to the Armenian Question: A Study in East Anatolian Prosopography (Phd Thesis). Los Angeles: University of California.

Sunkar, M. et al. (2015). Erzen (Garzan) Bölgesi'nde (Siirt) Uydu Görüntüleri Analizleri ile Tarihi Yerleşme Alanlarının Belirlenmesi ve Bu Yerleşmelerin Tahrip Olmasında Beşer Faktörlerin Etkileri. Coğrafyacılar Derneği Uluslararası Kongresi Bildiriler Kitabı, 21-23 Mayıs 2015, Gazi Üniversitesi, Ankara, 702-709.

Syme, S. R. (1983). Tigranokerta. A Problem Misconceived. S. Mitchell (Ed.), Armies and Frontiers in Roman and Byzantine Anatolia: Proceedings of a Colloquium held at University College, Swansea, in April 1981, Oxford: BAR, 61-70.

(1987). Exotic Names, Notably in Seneca’s Tragedies. Acta Classica, 30, 49-64.

Taylor, J. H. (1952). Political Motives in Cicero's Defense of Archias. The American Journal of Philology, $73(1), 62-70$.

Telford, L. (2014). Sulla: A Dictator Reconsidered, Pen and Sword Military Books, Barnsley.

Thomson, R. W. (1978). Moses Khorenats' $i$ : History of the Armenians. Translation and Commentary. Cambridge, Mass.-London.

Wylie, G. J. (1994). Lucullus Daemoniac. L'Antiquité Classique, 63, 109-119.

Wilcox, P. (1986). Rome's Enemies (3): Parthians and Sassanid Persians, Osprey Publishing. 


\section{FİGÜRLER}

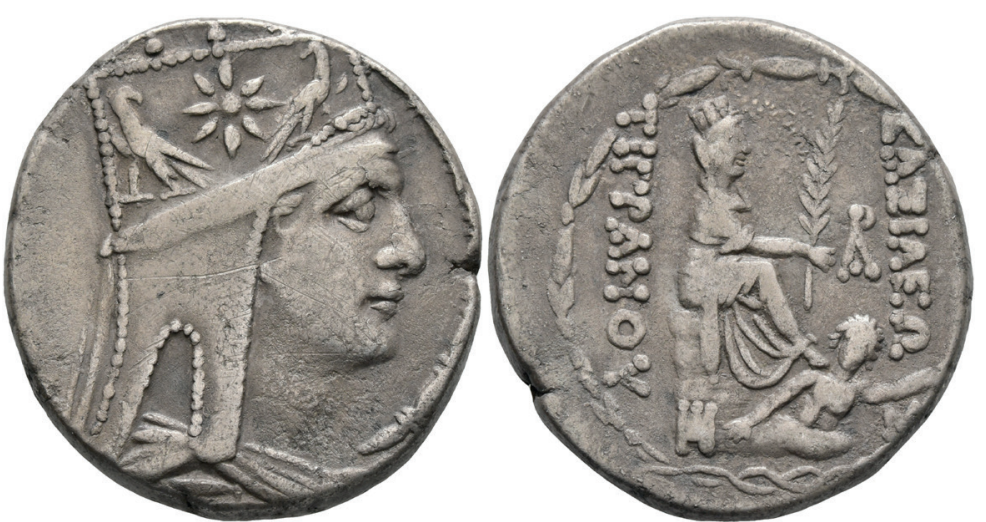

Figür 1. II. Tigranes (Gümüş tetradrachme sikkesi, MÖ ca. 80-68. Sağa doğru II. Tigranes. Başlık giymekte ve iki kartal arasında kuyruklu yıldızla dekore edilmiş beş-uçlu iara giymekte. Tersi. BA $\Sigma I \Lambda E \Omega \Sigma$-ТІГРАNOY. Taretli ve örtülü Tykhe sağda kaya üzerinde oturmakta, sağ elinin önünde uzun bir palmiye ağaç dalı tutmakta; altında nehir-tanrısı Arakses yüzmekte). https://www.coinarchives.com/a/results.php?search=Tigranes+II 


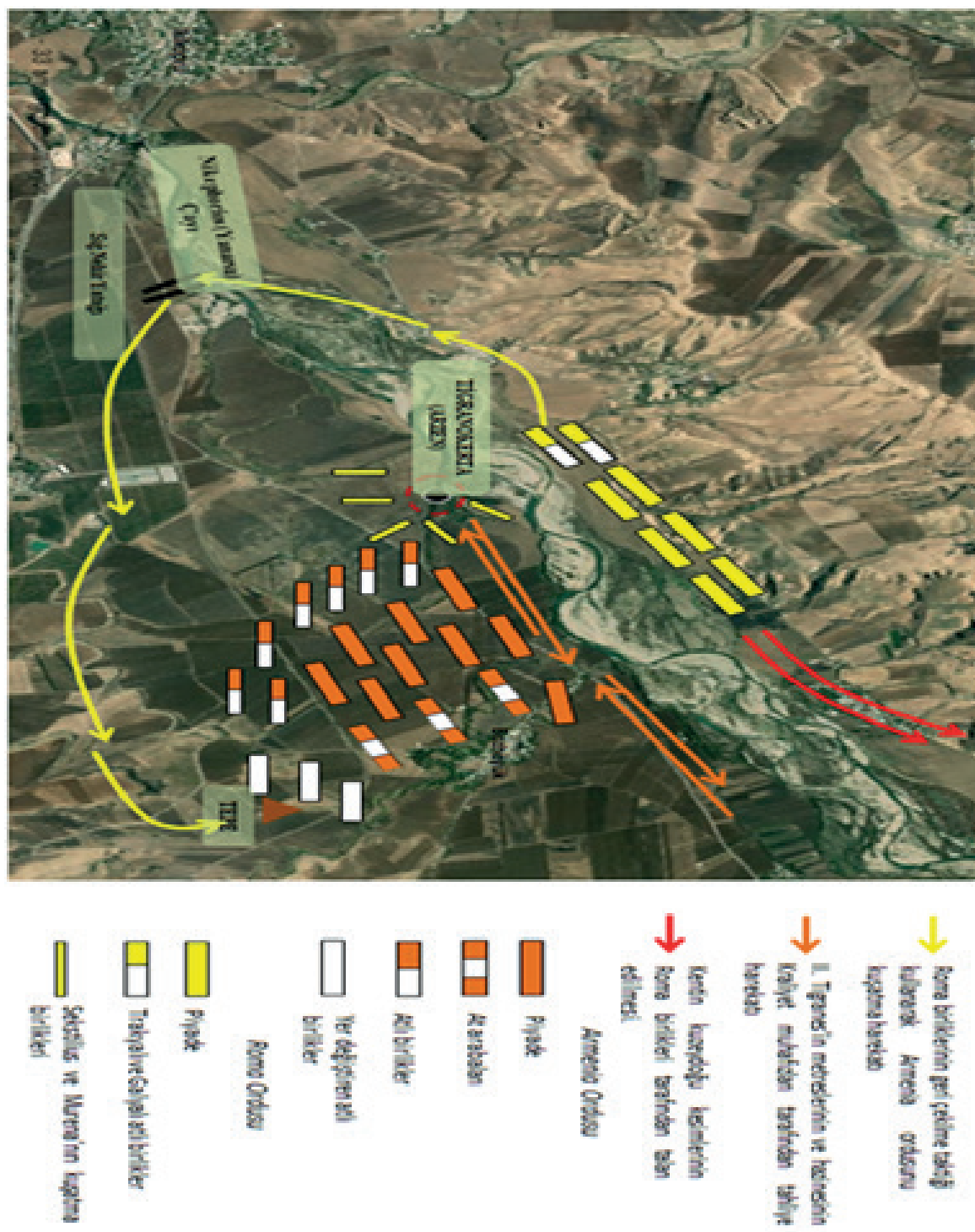

Plan 1. Savaş Harekâtı (Temsili) 